\title{
Future Options of the Kurds. Part II: Historical Background
}

\author{
Ferdinand Hennerbichler \\ Department of History, College of Humanities, University of Sulaimani (UoS), Sulaymaniyah, Iraq \\ Email: ferdinand.hennerbichler@univsul.edu.iq
}

How to cite this paper: Hennerbichler, F. (2018). Future Options of the Kurds. Part II: Historical Background. Advances in Anthropology, 8, 235-272.

https://doi.org/10.4236/aa.2018.83010

Received: July 30, 2018

Accepted: August 27, 2018

Published: August 30, 2018

Copyright $\odot 2018$ by author and Scientific Research Publishing Inc.

This work is licensed under the Creative

Commons Attribution International

License (CC BY 4.0).

http://creativecommons.org/licenses/by/4.0/

\begin{abstract}
The following second part of our analysis provides historical background information in order to better understand future options of the Kurds. We explain here in some detail why so far in contemporary history, virtually all efforts failed to achieve legitimate national rights for the Kurds and why they could and should not be repeated in the future. We basically show in sketched small historical chapters that Kurds to date could only win limited national rights, like some forms of autonomous regional self-rule. The reasons for that are in many aspects. Firstly, because they were used over centuries both by dominant central as well as foreign powers as proxies for their interests and also cooperated with them for own split aims. Second, because Kurds are chronically divided, constantly at loggerheads, disunited (Sheikhmous, 1992 \& 2013: "united in disunity") and fragmented. Thirdly, although they remain a considerable force of stability in Eurasia and the Middle East and are indeed underway to democracy they are still unable to come true majority rule of Western democracies. And last but not least, because they lack experience governing themselves and diplomacy to secure their own national rights with one strong united voice.
\end{abstract}

\section{Keywords}

Kurds, Iraq, Iran, Turkey, Syria, Israel, Saudi Arabia, Gulf States, Egypt, Russia, UN, USA, EU, NATO, Future Options

\section{Proclamations of an Independent Kurdish State}

Until now, no Kurdish leader proclaimed an independent greater Kurdish state for all Kurds and their extensive inter-regional habitat in Eurasia and the Middle East.

Historical Background: Keywords. Proclamation of an independent Kurdish state.

Since the collapse of the Ottoman Empire in the course of the First World 
War, only a few Kurdish leaders proclaimed an independent Kurdistan to this day: Sheikh Mahmud Barzanji (Mehmûd Berzincî, 1878-1956) during the then British UN Mesopotamian Mandate and the later Iraq, and Qazi Mohammed (1893-1947) in 1946 in northern Iran which was at the time occupied and dominated by Soviet troops. Barzanji declared in May 1919 a "United Free Kurdistan" that was crushed in the same year by the British and Barzanji was exiled to India. From there, he returned in 1922 in triumph well ahead of time and proclaimed on 10th October 1922 in Sulaimaniyah the "Kingdom of Kurdistan" with the aspiration to represent all Kurds. This "Kingdom of Kurdistan" survived in the shadow of the British until 1924 and was subdued in July 1924 by vastly superior British colonial forces (Hennerbichler, 2004: pp. 437-454). Qazi Mohammed founded the pro-Soviet "People's Republic of Mahabad" on January 22, 1946, which lasted eleven months until December 16, 1946, and was overthrown by the then reinvigorated Iranian army (Eagleton, 1963: pp. 62-118; Ramazani, 1971: pp. 401-427; Hennerbichler, 2004: pp. 512-517; Nerwiy, 2012: pp. 135-190).

Already in 1930, a "Republic of Ararat" emerged, named after Mount Ararat, in the wake of the so-called "Ararat uprising" in the north-east of the then newly formed "Republic of Turkey". The areas which it claimed came under Turkish control in 1931. The "Ararat uprising" was carried out by the Kurdish "Khoybun" (independence) movement, which was founded in Lebanon in 1927 and worked towards a free Kurdistan. Chairmen of the "Khoybun" were the brothers Celadet Ali and Kamuran Bedirkhan. The commanding General was Ihsan Nuri Pasha, who played a leading role in the "Ararat Uprising". The "Khoybun" finally appointed General Ibrahim Heski governor of the "Republic of Ararat". This Kurdish "Republic" was not recognized internationally. The foundation of a separate Kurdish Ararat "state" is still not conclusively validated (Hennerbichler, 2004: pp. 490-491). As a result, since the suppression of the "(People's) Republic of Mahabad", no Kurdish leader has proclaimed an independent state of Kurdistan. So far, neither has Masoud Barzani. His father Mustafa Barzani had repeatedly rejected the proclamation of an independent Kurdish state on the grounds that it was hopelessly surrounded by neighboring countries and not viable, because it would lack essentials to survive, like adequate weaponry, necessary financial resources and vital uninterrupted contacts to the outside world. Neighboring states just needed to close their borders to bring such a land-locked Kurdistan down. He further feared that Iraqi Kurdistan could decay into an international aid care case similar to encircled Berlin in the 1960s, which could overcome isolation and imminent collapse only with the help of Western allies and was ultimately saved by an extensive airlift over territories of a divided Germany at the time (Hennerbichler, 2004: p. 586). In Iran, the chairman of the "Democratic Party of Kurdistan - Iran (KDP-Ir)", Abdul Rahman Ghassemlou, who was tragically murdered in Vienna in 1989, repeatedly refused to proclaim an independent Kurdistan in north-western Iran. Ghassemlou had been encouraged several times by former Iraqi President Saddam Hussein at the beginning of the first Gulf War in the early 1980s to declare an own Kurdish state with 
the aim of weakening the rule of the "Islamic Republic of Iran". Saddam Hussein's regime would have taken over all costs for an independent Iranian Kurdistan beyond the Zagros. Ghassemlou, however, refused several times. His main reasons were that such a small separate Kurdish state on Iranian territory would not be viable and also against common Kurdish interests. ${ }^{1}$

\section{Russia and the Kurds}

Historical relations of Russia with the Kurds show extreme ups and downs. During WWI they culminated in massacres. At the end of WWII the Soviet Union indicated readiness to support a greater Kurdistan, but dropped the idea soon after and in 1946 backed a short lived "Kurdistan Republic of Mahabad" in NW Iran. In the Cold War period after WWII the Kremlin used Kurds mainly as proxies for their interests in Eurasia and the Middle East. Currently Russia holds out the prospect of treating Kurds even-handed with central powers, promote some forms of regional autonomy for them and announce significant investments in Iraqi Kurdistan.

\section{Historical Background: Keywords. Kurds and Russia}

Kurds play a not insignificant role for Russia's world power interests in Eurasia and the Middle East, although Kurds had developed in the past particularly since the 19th century a deep traditional distrust "of the power that for a century had been rolling back the frontiers of Islam in the Caucasus and posing a protector of native Christians against the Kurds of Turkey and Azerbaijan". Later Russian troops committed "excesses and brutality" during the First World War "extending to the border of Kurdistan" (Eagleton, 1946: p. 16). Since then relations changed gradually. During the First World War and after, both the abdicating Tsarist Russia, and the aspiring communist Bolsheviks, who threw themselves into world politics at the end of 1917, have used Kurds as proxies to extend their geostrategic spheres of influence southward all over (northern) Iran and also in Iraq. In Iran Russia utilized Kurds pressuring Teheran to grant Moscow oil concessions but failed several times until today. ${ }^{2}$ In Iraq the Kremlin used Kurds to gain control of oil- and gas-rich areas of Mesopotamia west of the

${ }^{1}$ Hennerbichler, 2013: p. 318; sources: verbal communication by Ghassemlou in the 1980s, personally confirmed also by former Iraqi President Jalal Talabani.

${ }^{2}$ See for details: Mamedova, 2009:

http://www.iranicaonline.org/articles/russia-ii-iranian-soviet-relations-1917-1991; Kuniholm, 2011: http://www.iranicaonline.org/articles/azerbaijan-v (both accessed 20 June 2018). In brief (quoting mainly Nina Mikhailovna Mamedova): In 1916 Russian industrialist A. M. Khoshtariya received the right to the concession for oil extraction in the northern regions of Persia. The Soviet government in 1925 bought out his allotted shares (65\%) in the Kavir-e Kuriān Company that owned several low-powered wells in the Semnān region. However, the government (later) did not recognize the legitimacy of the deal, which was part of the conditions for the withdrawal of Soviet troops during the Second World War. On 26 February 1921 the Soviet-Iranian Treaty was officially signed in Moscow. The issue of the oil concession was not settled definitively from a legal point of view. In 1946 the Iranian side, through their prime minister, Aḥmad Qawām (Qawām-al-Salțana), who visited Moscow in February 1946, was trying to speed up the withdrawal of the troops and agreed to the proposal of the Soviet side to grant the USSR a concession for exploiting oil in the Northern regions of Iran. On 4 April 1946, the Agreement on Oil was signed in Tehran. Upon signing the provisional communiqué, the USSR announced the withdrawal of the troops (from Iran). 
Zagros, and to manipulate waxing and waning central powers in Baghdad. Russia was also keen to gain access to vital trade roots in the north to the Mediterranean, and in the south towards the Gulf. Recently, leading Russian companies managed to secure lucrative oil and gas contracts in Iraq, noteworthy in the Kurdistan Region. ${ }^{3}$ This is currently interpreted that Russia would be resolved to enhance both its influence on Baghdad and the Iraqi Kurds alike, whether even handed remains to be seen.

In geostrategic terms, both Iran and the later Iraq (former Ottoman Mesopotamia) emerged since the end of the 19th century as most important regions for rising Great Powers like Russia and Great Britain ${ }^{4}$ who were particularly keen to intensify their expansionist political strategies all over Eurasia and the Middle East. They had one basic highly controversial interest in common, both needed oil and gas as decisive fuel to world power. Russia, for its part, is since then continuously trying to extend geostrategic spheres of influence southward, first over northern Iran, later all over Iran and beyond, most notably to oil and gas rich areas in the North and South of Iraq, and on top of that Russia also wanted to secure access to warm water ports, to the Gulf in the South-East and the Mediterranean in the South-West, as well as to vital international trade roots. Kurds are viewed by Russia in this regard both as usable "proxies" and as potential partners alike. However, each and every time (in recent history) when Russia felt it could not uphold anymore an equal handed policy towards central powers (in Teheran, Baghdad, Ankara or Damascus) and the Kurds, and that it had to opt either way, Moscow decided on a regular basis against Kurds. The contemporary development in short:

Even on her world-political death-bed, the Russian monarchy tried in 1916-1917 to establish, in the north-west of Iran, regional minority regimes, dependent on Moscow; however, these efforts were not successful. Later, in the middle of the 20th century, Soviet Russia managed to conjure up - temporarily two minority republics, Azerbaijan and Kurdistan. But here again it failed in the long run to create a belt of minority states to secure its geostrategic interests towards the South and Iran.

At the end of WWI, a mainly tribal, conservative Kurdish society in the northwest of Iran, broadly based on a single products economy like tobacco, vigorously resisted spreading Russian advances into north-western Iran continuing to fight for regional self-rule and as much independent as possible from the Finally, the 1946 Agreement on Oil was rejected by the (Iranian) parliament (majles), which declared it null and void, and in 1956 the Soviet side officially abandoned its claims to oil explorations by the Kavir-e Kuriān company.

${ }^{3}$ Zhdannikov, Dmitry (2018). The great Russian oil game in Iraqi Kurdistan. Reuters, London, April 19, 2018:

https://www.reuters.com/article/us-rosneft-iraq-insight/the-great-russian-oil-game-in-iraqi-kurdist an-idUSKBN1HQ1R3 (accessed 19 April 2018)

${ }^{4}$ See for Britain's policy in Kurdistan for example Ali, 1992: p. 464: "This continued policy, which dates back to the nineteenth century has the following distinct features. 1) persistent support of the regional powers in the Middle East in their efforts to suppress the Kurdish revolts which Britain viewed as a threat to the stability in the area; and 2) the readiness on the part of Britain to manipulate the Kurds in order to secure her imperial interests in the region." 
central powers. Their regional seat of power was then the city of Mahabad in the northwest of Iran. ${ }^{5}$ Conversely, tsarist Russian occupying forces (more precisely: mainly marauding, disoriented, undisciplined, often unpaid units of the then disintegrating tsarist army) intensified forays into the greater Mahabad area, crushing what were assumed to be regional pockets of resistance, and in 1915-1917 also perpetrated massacres in and around Mahabad, above all killing and displacing thousands of Kurds. ${ }^{6}$

1) Anglo-Soviet invasion of Iran 1941

Soon after Germany attacked the Soviet Union in 1941, two Allied powers, Britain and the USSR, invaded Iran without a declaration of war in order to pre-empt a German occupation of the country. Though, Iran was formally neutral, Reza Shah Pahlavi (1878-1944) was leaning towards Germany. Soviet forces occupied northern Iran, British took over the south, separated by a small buffer zone (Mojab, 2001: p. 74). Reza Shah was accused of being sympathetic to Nazi-Germany, was forced to abdicate and replaced by his young son Mohammad Reza Pahlavi (1919-1980), who reigned Iran from 16 September 1941 to 11 February 1979. The Soviets secured from the North of Iran supply lines to and from the Gulf, the British managed to obtain crucial oil concessions mainly from SW to NW of Iran, which the former failed to get for good after decades of unsuccessful negotiations. Subsequently, the Soviet Union tried to extend and consolidate its influence over the north of Iran by initiating and supporting the formation of pro-Moscow regional satellite "Republics" in Azerbaijan and Kurdistan.

${ }^{5}$ The first national census of Iran was taken in November 1956, ten years after the fall of the Mahabad Republic. No census data in Iran are available before 1956 (Mojab, 2001: p. 78; 2005: p. 358-366; Vali, 2011: p. 159). Estimates indicate for Mahabad a population of ca. 16,000 in 1945: Eagleton, 1963: p. 27: "population was 16,000 in 1945 and 22,000 in 1961"; Mojab, 2001: p. 78, quoting in ftn. 6 the Iranian "Ketāb-e Asāmi-ye Dehät-e Keshvar [The Registry of the Country's Villages]" (1950: p. 26). For end of 1948, Mahabad city population figures were given with about 16,455 of which 8,189 were women and 8,266 men. According to Ghassemlou, 1988: 15 ca. 95 percent of the Iranian Kurdish population in 1945 were illiterate. Mojab, 2001: p. 78 cites similar figures for 1946 and 1956; See also Chaliand, 1993.

${ }^{6}$ Fossum, 1918, 10: 7, 5-6 (quoting Fossum 1.c.: Mojab, 2005: p. 362: “In 1915, the Russian army massacred the male population of Sauj Bulaq (Mahabad) and took away about two hundred women for abuse"). See also: Nikitin, Basil (1941). La Perse que jai connue, 1909-1919, typed memoir, Paris: Bibliothèque INALCO, (Persian translation 1947), mentions pp. 234-238 atrocities and massacres; p. 312: In WWI military operations of Russians, Turks, Armenians, Assyrians and Kurds approximately 700,000 people were killed and countless cities razed to the ground. Further reading: Jawaideh, 2006: p. 258. Farrokh, 2011: p. 293:" Memories of past Russian atrocities by Tsarist troops in northwest Iran, most recently during the First World War, were very much alive among loca Kurds. [...] the Soviets trying to keep a low profile in the Mahabad Republic." Recent Mahabad translations and publications in Persian: Samady, Abdulla (2006), ed. \& transl.: Mahabad Magazine, no. 69, December 2006 (in Kurdish): pp. 6-9: Chalniko, Jan: Report on the murder of the Russian consul in Mahabad, Col. Alexander Ivanovitch Iyas (1869-1914); pp. 10-11: Parwizyian, Miraza Wahab, today Karimi, 1920: Memories [2 pages handwritten in Persian]. Ghazi, Hassan (2009), ed. \& transl.: Memories of Ludvig Olsen Fossum (1879-1920), quoted from: The Kurdistan Missionary no. 12, Sept. 1916 \& 10: 7, 1918, 5-6, in: Mahabad Magazine, no. 102, September 2009 (in Kurdish): pp. 3-5: "In the area of Mahabad alone 7670 people were murdered, thousands of women and girls were taken to Tabriz and even sold for \$5"; additional sources in: Mahabad Magazine, no. 105, December 2009, p. 4: "Russians massacred people and destroyed houses for three days and nights"; additional partial translations of Fossum's reports by Ahmad Ghazi published in Mahabad Magazine, no. 71, December 2006, pp. 5-6. Note: Research and translations: Abdol-Hamid Hosseini. 
In this connection the Kremlin promised for the first time known in modern history to support the establishment of a Kurdish (Soviet dominated satellite) state and a greater Kurdistan.

2) Soviets promise greater Kurdistan state

Between 1941 and 1945 the geostrategic situation of the Soviet Union in Eurasia and the Middle East changed significantly. In 1941 the USSR was a beleaguered victim of Nazi-Germany aggression trying to extend its influence from Kurdish regions behind the WWII lines but was largely unprepared for active work among the Kurds (Roosevelt, 1947: pp. 250-251; Eagleton, 1963: pp. 16-23, 41-42). In 1945, it acted as a buoyant victor of WWII taking full advantage of a fluid post-war situation and using the Kurds as "proxies" mainly to get oil-concessions and influence over Iran and beyond. Accordingly, the Kremlin adapted its attitude towards the Kurds from reluctant and vague promises for regional autonomy in 1941 to an active, even though only temporary and short-lived, cooperation in 1945-1946, establishing a Kurdish "Republic" in Mahabad in the northwest of Iran modelled on Soviet-style SSR satellites in the south of the USSR. The Soviet government acted in the person of Jafar Baghirov (1896-1956), the communist leader of the Azerbaijan SSR from 1932 to 1953, who executed the instructions of Georgian born USSR dictator Joseph Stalin (1878-1953). Baghirov first invited in 1941 (Eagleton, 1963: p. 16: "late 1941"; Roosevelt, 1947: p. 251: "in 1942”) some thirty Kurdish leaders, mainly rival tribal chiefs, feudal and conservative, who represented the Iranian Kurdish societies, to Baku, the capital of the Azerbaijani SSR. Among them were contrasting personalities like Sheikh Abdullah Effendi Gilani, the most respected Sufi religious leader in northern Iranian Kurdistan at the time, whose influence extended into Iraq and Turkey (Eagleton, 1963: p. 19-20), a son of Sayyid Taha of Shemdinan in Hakkari, Turkey, other representatives of more than sixty Iranian Kurdish tribes at the time, and also Qazi Mohammed (1893-1947), a bourgeois Mahabad intellectual, lawyer, judge of an Islamic court, a socially minded resolute personality of small stature and a dynamic speaker. The members of the group were carried by car to Tabriz, the capital of Iranian Azerbaijan, and from there by train to Baku and back again. Their first visit in Baku lasted two weeks. The Soviets replied ambiguous to Kurdish demands but showed already in 1941in Baku special respect for Qazi Mohammed, who later in 1946 became "President" of the "Kurdish Republic of Mahabad". A further, largely identical group travelled to Baku on the invitation of Baghirov in the second half of September 1945. This time, its Kurdish composition was already entirely selected by Qazi Mohammed and under his leadership. The Soviets had already picked Qazi Mohammed in the summer of 1945 as "their man" (Eagleton, 1963: p. 42) to run a future Kurdish "Republic" in Mahabad and the "Komala" movement as their political instrument. "Komala" was founded on September 16, 1942, as a clandestine party organization by a small group of some 15 middle-class merchants and local petty officials near Mahabad. The youngest was a nineteen-year-old student, the oldest at about fifty, a tobacco commissioner. They called them- 
selves “Komala”, “Committee" (in full: “Komala-i-Zhian-i-Kurd”, or “Committee of Kurdish Youth"). At the beginning no leader was chosen. "Komala" acted like a "democratically ordered grouping", with no "dominant clique" emerging within the party (Eagleton, 1963: p. 39). The movement had also Iraqi Kurdish roots. The "Hîwa" (Hope) party, founded in 1938 by the Iraqi Kurdish historian and writer Rafiq Hilmi (1898-1960), sent two members, the officers Mustafa Kushnaw and Mir Hadj Ahmed, as delegates and advisers to the founding ceremony of “Komala JK” in September 1942. The Iraqi Kurdish "Hîwa” maintained close links with the Iranian Kurdish movements until the downfall of the "Mahabad Republic" at the end of 1946. The influence of "Komala" spread rapidly and it soon became the political backbone of the nationalist independence aspirations of the Iranian Kurds (Roosevelt, 1947: pp. 250-251). In October 1944, a group of about twenty-four party members offered the leadership of "Komala" to Qazi Mohammed. He accepted and swore the oath but was "never elected to the Central Committee" (Eagleton, 1963: p. 39; Roosevelt, 1947: p. 253 explains the delayed acceptance of Qazi Mohammed as leader with fears of founding party members that he "would eventually dominate the party and end its democratic character". "Komala" "did finally admit him" "at Soviet insistence", Roosevelt wrote and found that the result was a "one-man rule of the party").

In the meantime, the Soviets had altered their position between 1941 and 1945 towards the (Iranian) Kurds decisively. At the first meeting in Baku in late 1941 Jafar Baghirov, the PM of the Azerbaijan SSR at the time and acting on behalf of the Kremlin, was rather cautious when discussing Kurdish demands, speaking largely in general terms and communicating mainly the impression that the Soviet Union was with the (Iranian) Kurds. National Kurdish aspirations were only vaguely touched upon (Eagleton, 1963: pp. 23-24). Soon after in May 1942, Kurdish tribal leaders already in claimed frank terms in discussions with Russian officials in Tabriz and Rezaieh demanded freedom in national affairs (Eagleton, 1963: p. 24). During the year 1944 both Azerbaijan and Kurdistan in Iran were already filled with Soviet political officers and other agents (Roosevelt, 1947: p. 251). In the summer of 1945 the demand for Kurdish autonomy was openly discussed with the Russians on a regular basis.

At the second meeting in Baku in September 1945 the Kurdish delegation entered into negotiations with written demands for a separate Kurdish state and comprehensive assistance from the Soviet Union, in particular for arms, supply and money. Their draft proposals were slowly written down by Qasim Ilkhanizadeh from Bukan, chosen “because of his fine hand” (Eagleton, 1963: p. 44). Baghirov indicated in a keynote speech the readiness of the Soviet Union to grant the Kurds a greater Kurdistan state comprising the Kurdish areas of Turkey, Iraq and Iran. However, as he literally said, there was no need for the Kurds to hurry the formation of their own state. Kurdish freedom must be based not in Iran alone but also in Iraq and Turkey. A separate state was only desirable in the future when the entire Kurdish "nation" could be united. In the meantime, Kurdish aspirations should be achieved by autonomy of the Kurds within a greater 
"Republic" of Azerbaijan. In his answer speech Qazi Mohammed made it once again clear that the Kurds of Iran wanted autonomy and independence separate from that of Azerbaijan. Banging his fist on the table, he proclaimed that "as long as the Soviet Union exists the Kurds will have their independence" and concluded that since the Kurds had been promised their own state by the Soviets they would also expect to receive all necessary means to defend it and make it prosper (Eagleton, 1963: pp. 43-45). Baghirov finally urged the Iranian Kurds to dissolve "Komala" and transform it into the "Democratic Party of Kurdistan" ("Hizb i Demokrat $i$ Kurdistan") in line with the "Democratic Party of Azerbaijan", which was publicly announced in Tabriz on September 3, 1945. Baghirov also referred to the armed revolt of Mulla Mustafa Barzani in northern Iraq and warned that he "was a British spy", which, however, did not concern the Iranian Kurdish delegation in Baku much (Eagleton, 1963: pp. 45-46).

3) Formation of the "Democrat Party of Kurdistan" Iran 1945

The "Democratic Party of Azerbaijan" evolved in September 1945 as an independence party to replace the "Tudeh" of Azerbaidjan. The "Tudeh Party" ("Hezb-e Tüdeh-e Irān", Party of the masses [the people] of Iran) was a popular front of Marxist left-wing movements that had been used by the Soviet Union as political instrument to penetrate Iran. Although it was successful in other parts of Iran, it had never taken root in Kurdistan. "Tudeh" abolished itself, reformed as the "Democrat Party of Azerbaijan", used Azeri Turkish as its official language and demanded separation from Iran (Roosevelt, 1947: p. 253; Lenczowski, 1947: pp. 29-45). In contrast, the "Democrat Party of Kurdistan" was formed out of the Kurdish nationalist "Komala" independence movement which neither had communist party nor Soviet inspired Marxist ideological roots. The formation of the "Democrat Party of Kurdistan" was formally announced by Qazi Mohammed after his return from the second trip to Baku at the end of September 1945. He called a foundation meeting in Mahabad and urged all Kurds to join (Roosevelt, 1947: p. 254). A "Manifesto" was issued, signed by Qazi Mohammed and 105 leading Kurds. It invoked the "Atlantic Charter" of August 14, 1941, agreed upon by U.S.-President Franklin D. Roosevelt and UK Prime Minister Winston Churchill, ${ }^{7}$ indicating as the goal of the party "democracy on the American model". The "Atlantic Charter" summarized in eight fundamental points sketches for a new peaceful and stable post WWII world order: point 2: "no territorial changes that do not accord with the freely expressed wishes of the peoples concerned"; point 3: "the right of all peoples to choose the form of government under which they will live; and they wish to see sovereign rights and self-government restored to those who have been forcibly deprived of them". The foundation of the new party resulted in the dissolution of the "Komala JK" and the absorption of its members by the Kurdish Iranian "Democrats" (Roosevelt, 1947: p. 254). It “took twenty days to get everything ready" (Eagleton, 1963:

${ }^{7}$ Issued as joint declaration and statement (no formal legal document) at Naval Station Argentia, a former U.S. Navy base 1941-1994, which later became the tenth province of Canada, Newfoundland and Labrador; cited online-version: http://avalon.law.yale.edu/wwii/atlantic.asp (accessed 03 March 2018). 
p. 56). In November 1945, Qazi Mohammed called together some sixty tribal and town leaders at the newly opened Soviet cultural relations center in Mahabad. Russian officials stayed away. Qazi delivered a speech, reviewed the (second) Baku trip and recalled Baghirov's advice that the until then clandestine "Komala JK" should dissolve, change its name and come into the open under the banner of democracy. Questions or comments? he asked. "None. The issue was decided" (Eagleton, 1963: p. 57). The change in name was not accompanied by fundamental alterations in the party organization. The composition of the Central Committee was not immediately modified. Qazi Mohammed had not been a member in the old party, nor did he become one in the new one. He "merely continued to dominate the Kurdish movement, with Russian advice from behind the scenes" (Eagleton, 1963: p. 57). The "new" party also had a program ${ }^{8}$ which was in essence similar to the "Manifesto" declaration. Neither called for separation from Iran nor for a Kurdish Iranian break-away state. Instead, it proclaimed the following goals (quoting from the eight-point "Manifesto"): in short: self-government in local affairs and autonomy within the limits of the Iranian state: a) "The Kurdish people of Iran should have freedom and self-government in the administration of their local affairs and obtain autonomy within the limits of the Iranian State." b) Kurdish should be the official language. c) "The provincial councip of Kurdistan should be immediately elected according to constitutional law and should supervise state and social matters." d) "All state officials must be of local origin." e) “ $A$ single law for both peasants and notables should be adopted...” f) "[...] make a special effort to establish unity and complete fraternity with the Azerbaijani people and the other peoples that live in Azerbaijan (Assyrians, Armenians, etc.) in their struggle." g) “[ ] will strive for the improvement of the moral and economic state of the Kurdish people through the exploration of Kurdistan's many natural resources, the progress of agriculture and commerce, and the development of hygiene and education." h) "We desire that the peoples living in Iran be able to strive freely for the happiness and progress of their country." The KDP-I program consisted in a full length version of four main parts and twenty-two articles (see Nerwiy, 2012: pp. 130-131).

4) Inauguration of the "Kurdish People's Government" and "Provincial Council"

On December 15, 1945, five days after all eastern Azerbaijan fell under the control of the newly formed "Azerbaijan People's Government" in Tabriz, the Iranian Kurds inaugurated their own regional government in Mahabad. At a meeting in Mahabad, called for by Qazi Mohammed, the "Kurdish People's Government" was established and a "provincial councip" formed. The meeting was attended by tribal chiefs, members of the new Kurdish Democrat Party, and three Soviet officers in a jeep armed with Tommy guns (sub-machine-guns). The Iraqi tribal leader Mullah Mustafa Barzani (1903-1979) was also present (Roosevelt, 1947: p. 257; cf. also: Eagleton, 1963: p. 61; Blake, 2009: p. 33, refer-

${ }^{8}$ Roosevelt, 1947: p. 255 published an eight-point “Manifesto", Eagleton, 1963: p. 57 “one version" of a party program which is composed of seven points but is in its content similar to the "Manifesto" declaration.

${ }^{9} \mathrm{~A}$ (freely elected) "Parliament" was not mentioned. 
ring to Roosevelt \& Eagleton; further: Nerwiy, 2012: pp. 127-131).

5) Aftermath of the failed pro-Nazi-German coup in Iraq

Mustafa Barzani played a decisive and leading role as the self-exiled Iraqi Kurdish leader in the short-lived "Republic" of Mahabad in Iran. ${ }^{10}$ After a failed rebellion against the Iraqi government he fled Iraqi Kurdistan to Iran in October 1945 with "Peshmerga" and family tribe members. ${ }^{11}$ They defected to Iran after Barzanis had tried to use a severe internal crisis in Baghdad to gain national rights for the Kurds in Iraq but failed. The crisis was triggered by a pro-Nazi-German military coup d'état in Baghdad under the Iraqi Prime Minister at the time, Rashid Ali al-Gaylani (1892-1965), who attempted to negotiate deals with Axis powers in order to counter British influence in Iraq. Subsequently, British forces intervened in the so-called Anglo-Iraq War (April-May 1941), quelled the coup and re-occupied the Hashemite kingdom of Iraq until 26 October 1947.

6) Proclamation of the "Kurdistan Republic of Mahabad"

In the mid-morning of January 22, 1946, a sunny and mild winter day, the "Republic" of Mahabad" was formally proclaimed at "Chwar Chira" or "Four Lamp/Candle Square" (Eagleton, 1963: pp. 62-63; Roosevelt, 1947: p. 257). Qazi Mohammed held a short fifteen minutes proclamation speech on a wooden platform, wearing a Soviet-style army uniform that had just been made for him in Tabriz, and the white turban of a religious dignitary. He said the Kurds were a people apart, occupying their own land and sharing with other nations the right to self-determination. Amid cheers he thanked the Central Committee of the party and the people of Kurdistan for heaving chosen him to lead the new nation, and the Soviet Union for moral and material support. Eagleton, 1963: p. 63: “An autonomous Kurdish Republic was from that moment established". It was the first Kurdish experiment in forming a modern-style autonomous government (Mojab, 2001: pp. 77-79), was in practice independent of the Iranian state even months before the proclamation of a "Republic" but acted de facto always within the borders of the then Iranian Kingdom. The founder of the "Republic" was not a tribal or feudal leader but rather a new party which demanded the creation of a greater Kurdistan, though its territory (influence area) was limited to the northern parts of Iranian Kurdistan. The "President" of the "Republic", Qazi Mohammed, was chosen by leading KDP-Ir party members. He also was empowered as supreme commander of a "National Army". This replaced the former Iranian army and gendarmerie structures and was mostly led by Kurdish officers who had deserted the Iraqi and Iranian armed forces. The Iraqi Kurdish tribe leader Mustafa Barzani emerged as the most powerful and dynamic military leader of the Iranian Kurdish armed forces. Barzani "Peshmerga" formed the de-

\footnotetext{
${ }^{10}$ Laqueur, 1956: p. 230: “[...] Qadi Muhammad used the Barazani tribe as his main military force [... and] antagonized other tribes."

${ }^{11}$ Farrokh, 2011: p. 287: "along with 1000 - 3000 of his warriors and their families"; Arfa, 1966: p. 79 cites 3000; Ward, 2009: p. 182: "one thousand experienced Iraqi Kurdish fighters";

${ }^{12}$ Officially "Republic Kurdistan" (Kurdish: "Komara Kurdistan” or "Komara Mehabadê"), also called "People's Republic".
} 
cisive backbone of the Mahabad republican army. ${ }^{13}$ The party was the legislative, executive and judiciary power altogether. A parliamentary democracy did not evolve, and a democratically elected parliament not exist. ${ }^{14}$ The party neither created a mechanism for free elections nor did it hold a congress as promised in its constitution. A cabinet and a council were formed. The cabinet was composed of thirteen "Ministers". Haji Baba Sheikh was Prime Minister and Chief of the Supreme Court, Mohammed Hosein Khan Saif i Qazi, a cousin of Qazi Mohammed, was Minister of War and Assistant President of the "Republic". He had a reputation as merchant and a loose military one with a former honorary rank in the Iranian gendarmerie. Mustafa Barzani was not a Minister and did not belong to the Mahabad republican government. In its historical context, the Kurdish Republic of Mahabad can be seen as a modern example of the world's largest "stateless" or non-state nation with a long history of sovereign rule (Mojab, 2001: p. 3). Shahrzad Mojab is distinguishing "this state from its pre-modern predecessors not only by its republican form, which was administered by a political party and a cabinet, but also by its modern educational system, modern media, national army, tax system, national anthem, national flag, national language, and mobilization of women into educational, cultural and political life." The exercise of state power was, however, in all cases of Kurdish history male gendered (Mojab, 2001: p. 3, 77-79; Hassanpour, 1992 \& 1994).

7) Downfall of the "Kurdish Republic"

The Mahabad "Republic" survived with transitory and rather limited support by the Soviets approximately 11 months until December 16, 1946. Following mounting pressure after WWII by Western allied powers, notably the USA, to immediately withdraw from Iran, the Soviets eventually pulled their occupying forces back from Iran and ultimately also dropped their support for the short-lived "Kurdish Republic of Mahabad". Iranian forces, resurgent under the then young Shah Mohammad Reza Pahlavi, reoccupied Mahabad in December 1946 and quelled the "Kurdish Republic". Its President Quazi Mohammed (1900/1901-1947) was sentenced to death along with his ministers for "sedition", "secession" and "treason". They were executed ${ }^{15}$ on March 31, 1947, with the exception of one who was given immunity according to his high religious status. The short-lived "Kurdish Republic of Mahabad" collapsed above all because the Soviet Union dropped them after it became clear to the Stalin regime that it

\footnotetext{
${ }^{13}$ The most reliable figures about the strength of Kurdish "Peshmerga" at the time of the Mahabad "Republic" are still provided by Eagleton, 1963: pp. 91-93. Additional figures are given among others by Lortz, 2005: pp. 27-30 and Nerwiy, 2012: pp. 151-153. Therefore, the estimated hypothetical military strength of all involved Kurdish tribes at the time was around 10,000 to 15,000 soldiers. Barzanis from Iraq contributed the by far strongest and dominant Kurdish military forces which formed the backbone of the Mahabad "National Army". Of these, 1,200 were under the superior command of Mustafa Barzani, and 900 under Sheikh Ahmad, an older brother, but not at the front, and both were infantry.

${ }^{14}$ Therefore, remarks like Roosevelt, 1947: p. 257: “A national parliament of thirteen members was formed, and on January 22, 1946, Qazi elected president of the new Republic" are both not entirely correct.

${ }^{15}$ On March 31, 1947, 3 a.m., Ghazi Mohammad, Seif Ghazi and Sadr Ghazi, were hanged on three separate gibbets at the Chwar Chira circle night ( 3 a.m.) at the same place where fourteen months earlier the Republic of Kurdistan had been proclaimed (Nerwiy, 2012: p. 190; Eagleton, 1963: p. 122).
} 
could neither use the Kurds to get oil concessions from Iran nor improved influence over the central power in Teheran under Shah Mohammad Reza Pahlavi. Additional factors included the absence of promised military, financial and geo-strategic support by the Soviet Union, ${ }^{16}$ endemic inter-Kurdish (tribal) rivalry, fragmentation and disunity, and last but not least its inexperience in running government institutions (Ghassemlou, 1988: pp. 135-136; Nerwiy, 2012: p. 182). However, the Kurdish "Republic" of Mahabad was not a Soviet "puppet" state. ${ }^{17}$

8) No break-away Kurdish state from Iran

The Kurdish "Republic" of Mahabad was a short-lived independent (self-ruled) "state" but never broke away from the territory of the then Iranian monarchy. It developed its own regional administration and issued official documents such as birth certificates, but had no clear, final and secured border, and therefore no own fixed territory. Also, its administrative and political terminology was ambiguous. For example, it used different words for Ministries and changed terms for Ministers (from "wazir" to "rais"). Its leaders did not have a precise clear-cut vision of the term "Republic" either. ${ }^{18}$ They neither interpreted, understood nor used the terms "republic" or "state" exclusively in the sense of creating a break-away state from Iran. Rather, they insisted several times that they acted intentionally within the Iranian constitution by merely invoking the global right of (all peoples) to self-determination ${ }^{19}$ and establishing local/regional self-rule similar to models that already existed at the time. These models included the national minority "states" (SSRs) within the "Soviet Union" (of states), or like a federal member-state of the United States of America, and to ${ }^{16}$ Laqueur, 1956: p. 224: “But the Soviet government apparently did not consider at all their political potentialities, and did not want to appear as a 'Kurdlsh power' in Middle Eastern politics." 231: "The Russians, who had promised much help, did not provide any, and in the end Qadi Muhammad was betrayed by all."

${ }^{17}$ The term "puppet" would indicate a totally submissive Iranian Kurdish existence to Soviets which was evidently not the case. Kurdish scientists like Amir Hassanpour (1943-2017) and his widow Sharzad Mojab are publishing since decades evidence disproving "puppet" labels for the Mahabad "Republic" (cf. for instance Hooglund's obituary 2018: MEC 27, 95-98: “Amir was quite passionate about the Mahabad Republic, insisting that it never was a Soviel-created puppet regime, as the Iranian government and US scholars claimed, but an effort by Kurds, who genuinely wanted local autonomy for administering their towns and villages and to obtain recognition of their right to teach Kurdish in the public schools.") Similar views are also expressed by younger Iranian scholars like Khandagh, 2013: p. 4: “Western writers are mistaken in assuming the party to be a Soviet puppet [,,]. The true cause of the revolution was not communist-inspired by the USSR, but due to the abject poverty within Kurdistan, a situation ignored by the central government. The movement was purely a nationalist movement that sought to establish Kurdish as the official language in schools and local government, and, quite independent from the Soviet Union. The USSR became involved only through the Kurds need for material support that was not forthcoming from the Iranian government." Examples for dissenting views: Coene, 2009: p. 102, 136; Farrokh, 2012: p. 283, 288, 293: "Many Kurds realized that theirs was not a truly independent Kurdish state but a Soviet puppet state."; Wilber, 2014: p. 136; Encyclopaedia Britannica (2018): "short-lived Republic of Mahābād, with a Soviet-backed puppet government”, online: https://www.britannica.com/place/Mahabad (accessed 20 June 2018).

${ }^{18}$ Nerwiy, 2012: p. 139: "the term republic implies a sovereign country with clearly defined borders. Although the Kurdish government enjoyed a certain level of sovereignty within the geographicai areas that it controlled, it was certainly not fully sovereign and it had border conflicts [...]." Ftn. 471: "the use of the term 'Republic by the Kurdish leaders is highly indicative of their ignorance regarding political science, diplomacy, and governance." 
quote but one example from Europe, the "Freistaat Bayern" ("Free State of Bavaria") in Germany. That is why it may be assumed that they followed primarily oscillating tactics between the option of becoming another Soviet dominated state, which a clear majority of (Iranian) Kurds at the time did not want, ${ }^{20}$ and meaningful regional self-rule within the Imperial Iranian monarchy, which did not materialize. ${ }^{21}$ At the end the attempt failed to secure a self-determined future for (Iranian) Kurds in an emerging post-WWII-order, by way of an intermediate existence between a Soviet- or Iranian-dominated option. However, the majority of Kurdish leaders at the time felt themselves closer to the Iranian culture (inter alia because Kurds speak since millennia northwestern languages of Iranian) than to Russian ones. ${ }^{22}$ In the secret military "Court Martial" against Qazi Mohammed in January 1947 in Mahabad, the prosecution cited an indictment containing 22 points (Nerwiy, 2012: pp. 188-190; Eagleton, 1963: pp. 123-124). Basically, he was accused of violating the Iranian constitution, armed rebellion and treason. ${ }^{23}$ Qazi Mohammed pleaded not guilty invoking the international right to take up arms against "political despotism" in self-defense of the Kurdish people $\mathrm{e}^{24}$ and to self-determination ("indigenous self-rule"). A specific indictment was made against his cousin Saif Qazi, a merchant with an honorary lower rank in the Iranian gendarmerie, for wearing a general's uniform and participating in fighting (Kurdish resistance against the Iranian military). However, the procedure of the military prosecutor to base a death-sentence indictment against one defendant specifically on the wearing of "a general s uniform" appears unusual and is not entirely clear. First, the Kurdish "Republic" of Mahabad had all in all four "generals" (since the end of March 1946), but neither had its own "generaP $s$ " uniforms nor did it use official and original ones of the Imperial Iranian army or Soviet "Red Army". Secondly, in use were Russian-style uniforms, but manufactured in March and April 1946 by local tailors from Mahabad to

${ }^{19}$ Eagleton, 1963: p. 63. Laqueur, 1956: p. 229: "Several interesting differences between the programme of the Mahabad Republic and those of the Kurdish Democratic Party in Persia and its sister party In Iraq should be noted. Qadi Muhammad was in favour of Kurdish autonomy within the Persian state. The Iraqi Kurdish Party, on the other hand, demanded a federative Iraqi state, but freedom for the Kurds in their foreign policy, too. They also demanded the nationalization of all naturai resources - while preserving ownership of the land - economic development, and an increase in the standard of living, as well as separation of the 'Church' from the 'State.".

${ }^{20}$ Ghassemlou, 1988: pp. 50-51; Nerwiy, 2012: p. 181.

${ }^{21}$ Westermann, 1946: p. 686: "no experience of self-rule"; Ghassemlou, 1988: pp. 135-136: Inexperience in running government institutions was one course of the fall of the Republic of Kurdistan. Their leaders had no experience in politics and were ignorant in establishing and administering a civil government. Cf. also: Nerwiy, 2012: p. 182.

${ }^{22}$ Farrokh 2011: 293: "The Soviets hoped to merge all Kurds into Soviet Azarbaijan, but the Kurds felt that if they should join a larger state, they had far more affinity with Iran. When the Iranian army arrived in December 1946, the vast majority of Kurds (like the Azaris) showed little desire to die on behalf of Moscow." See also: Arfa, 1966: p. 86, 101.

${ }^{23}$ Nerwiy, 2012: p. 188: "The first indictment referred to the establishment of the Republic of Kurdistan, attempts to secede and fracture Iranian territorial integrity, the formation of the Nationai Army and award military ranks, to bring down the flag of Iranian government and replace it with the Kurdish flag, relations with outsiders (Soviets)."

${ }^{24}$ The Kurds see the right to armed resistance against political despots inter alia in contemporary history confirmed by UNSCR Resolution 688 (1991) of April 5, 1991, against the Saddam Hussein Regime in Iraq: http://unscr.com/en/resolutions/688 (accessed 20 April 2018). 
Rezaieh and Tabriz, that "nearly all persons connected with the Kurdish Government or army could" wear "looking like Soviet officers in khaki with boots, riding breeches, and caps", as Eagleton explained (Eagleton, 1963: p. 79). The first to wear such a local Kurdish-designed-version of Russian-style uniforms was Qazi Mohammed at the proclamation ceremony of the "Republic" on 22 January 1946. Subsequently, many Kurdish tribal chiefs wanted such a new Russian-style uniform too, because they made them look like commanding Soviet officers, as Eagleton noted and later Ghassemlou, 1988: p. 75 confirmed. Ghassemlou recalls "tribal leaders who asked Ghazi Mohammad to acquire for him another military rank, which when he returned to his village, would create more respect for him" (Nerwiy, 2012: p. 153). As for awarding higher military ranks, Roosevelt, 1947: p. 257 noted that in the course of the "Republic" proclamation on January 22, 1946, leading Kurdish tribal leaders like Zêro Beg Herki received the (honorary) rank of "marshap" and were "provided with Soviet uniforms, complete with high boots, stiff shoulder-straps, and red-banded garrison caps." The motive was to secure their support for the "Republic" under Qazi Mohammed. The rank of a "marshap" was also awarded to the Iraqi Kurdish tribal chief Mustafa Barzani (Lortz, 2005: p. 28 citing Roosevelt, 1947: p. 257). In the second half of February 1946 commanders of the newly formed "National Army" announced sweeping military reforms. On 31 March 1946 the Mahabad government appointed four generals, one of whom was Mullah Mustafa Barzani (Eagleton, 1963: p. 136; O’Balance, 1996: p. 30; Nerwiy, 2012: pp. 148-150). “ $\mathrm{He}$ proudly retained his rank and used it for the rest of his life", the British military historian Edgar O’Balance wrote. ${ }^{25}$ However, neither Mustafa Barzani nor any other Kurdish military commander in the army of the Mahabad "Republic" was ever given the rank or the uniform of the Soviet Army. ${ }^{26}$ To sum up: out of four "National Army" "generals" of the Mahabad "Republic" only one was specifically indicted after its downfall for "wearing a generals uniform" and was finally hanged after his conviction inter alia because of that. The incriminated uniforms were locally Iranian Kurdish designed and manufactured, modelled on Soviet-style uniforms and had mainly an honorary character.

9) Mustafa Barzani in the USSR 1947-1958

Mustafa Barzani together with "more than 500 Peshmerga" (Barzani, 2003: p. 361; Lortz 2005: p. 34; Koohi-Kamali 2003: p. 122: “about 500 - 800 men”) and their families left Iran for the Soviet Union. They crossed the Araxes river into the USSR on 18 June 1947. Their fate there was described from the Soviet point of view, notably by Pawel Anatoljewitsch Sudoplatov ${ }^{27}$ and Vasili Nikitich Mitrokhin $^{28}$. Sudoplatov, a lieutenant-general of the Soviet domestic intelligence service (NKVD) and head of "Administration for Special Tasks" of the KGB, the Soviet secret service, described the attitude of the Soviets towards Mustafa Barzani and

\footnotetext{
${ }^{25}$ O'Balance, 1996: p. 30 concluded: “Barzani was secretly lobbying the Soviet authorities to appoint him president in place of Qazi Mohammed, who seemed at times to lose control of events. However, the Soviets refused as they did not trust Barzani, and in any case they no longer cared as they were in the process of withdrawing."

${ }^{26}$ This is also confirmed by Barzani, 2003: p. 140.
} 
the Kurds in very blunt detail. In short (quoting Sudoplatov \& Sudoplatov: 1994-1995: p. 259 et seqq.): Barzani and his entourage "broke through the lranian border and entered Azerbaijan", he writes. They "had been ambushed by the shah's forces and abandoned by British and American supporters." Barzani's "task force contained two thousand men with small arms and artillery, accompanied by a thousand family members." The Soviet government "first interned them in a camp", where Sudoplatov met him for the first time in 1947, after having been sent by a superior, Viktor Abakumov", to Baku "with instructions to offer Barzani political asylum for both troops and families, with temporary settlement in rural Uzbekistan not far from Tashkent", Sudoplatov noted. He managed to get Barzani to enter into a contractually determined "political alliance with the Soviet government", whereby the Soviet Union (only) promised "fully support" for a "Kurdish Republic" (headed by Mustafa Barzani) in border areas of Turkey, Iraq and Iran, but ultimately in rather more realistic terms - as Sudoplatov put it - merely composed of a (pro-Soviet) "Kurdish Republic" in territories of northern Iraq only, further accompanied by autonomous Kurdish regions in Turkey and Iran (Sudoplatov \& Sudoplatov, 1994-1995: p. 261). In return, however, Moscow agreed only to the formation of a Kurdish government in exile and proposed that the "Democratic Party of Kurdistan KDP" should get an office on a collective farm ("kolkhoz") near the Uzbek capital Tashkent, and that Mustafa Barzani become chairman of its Central Committee. Moscow also advocated training a brigade of about $1500 \mathrm{KDP}$ "Peshmerga" in sabotage techniques. The intention was to overthrow the then government in Baghdad of veteran Prime Minister Nuri as-Said (1888-1958), undermine Britain's dominant influence in Iraq, and enable the Soviet Union to influence and control vital European and US strategic oil supplies, ultimately including the option of destroying pipelines in Iran and Iraq. When Barzani invited Sudoplatov to meet with his staff of thirty "Peshmerga" officers, they first stood at attention, but then "all of them fell to their knees and crawled toward Barzani, begging his permission to touch and kiss the hem of his gown and his boots". Sudoplatov reacted with a mixture of shock and disillusionment and noted: "All illusions of democratic Kurdistan evaporated from my mind", concluding: "it was clear to me that the plan [creation of a democratic Kurdistan under Mustafa Barzani] was one of the ideological fantasies created [by the then Kremlin party apparatus] in the Central Committee offices on Staraya Ploshchad [in Moscow]" (Sudoplatov \& Sudoplatov, 1994-1995: p. 261). Afterwards, in April 1952, “Barzani settled down near Tashkent, surrounded by his family and his countrymen in a large collec-

\footnotetext{
${ }^{27}$ Pawel Anatoljewitsch Sudoplatov (1907-1996), Lieutenant-General of the Soviet domestic intelligence service NKVD, head “Administration for Special Tasks" of the Soviet secret service KGB; Sudoplatov, Pawel, \& Anatoli (1994-1995): pp. 259-264, 294, 415.

${ }^{28}$ Vasili Nikitich Mitrokhin (1922-2004), leading keeper of the archives of the Soviet foreign security service; defected 1992 to the British intelligence service MI6with a large collection of KGB files known as the "Mitrokhin Archive", exposing numerous Russian agents; Andrew \& Mitrokhin (2005): pp. 175-176, 536. See also Smolansky \& Smolansky (1991).

${ }^{29}$ Viktor Abakumov (1908-1954), high level Soviet security official, from 1946 to 1951 Minister of State Security or MGB (former NKGB). He was notoriously brutal and known to torture prisoners personally.
} 
tive farm", Sudoplatov wrote. The Soviet Union finally supported Kurds in the 1950s and 1960s but dumped them again in the early 1970s (Sudoplatov \& Sudoplatov, 1994-1995: pp. 263-264). In the 1950s "the Kurds were Russia's only allies in the area, but later our strategic alliances with lraq and Syria became the dominant factor in Middle East politics", Sudoplatov explained. During Sudoplatov's involvement in Kurdish affairs the 1950s the main purpose was "to take advantage of the Kurdish movement in the confrontation of the Cold War." Playing with the option of setting up a "republic of Kurdistan" for the Kremlin was "an attractive instrument for pursuing our policy in the Middle East", and "a way of undermining British and American interests and positions there" at a time when the balance of power was rapidly drifting away from Moscow. In the 1960s Mikhail Suslov ${ }^{30}$ succeeded Sudoplatov in working with Barzani. Suslov "promised all-out support for Kurdish autonomy for overthrowing Nuri Said in Iraq". After Nuri Said's government was overthrown in a military coup with the support of the Soviet Union, the latter "acquired allies in the area who were far more important for [Moscow's] geopolitical considerations than the Kurds." In consequence, in the 1970s the Soviet Union "abandoned the Kurds in their struggle." Sudoplatov's sobering conclusion: The Soviet Union had been aiming "to turn the Kurds into our strategic ally to control who ruled lraq" but failed. Kurds were used by the Kremlin to undermine the interests and positions of British and Americans during the Cold War in the Middle East but were "tragically manipulated" over and over. In retrospect, for Sudoplatov it is "clear that the superpowers had no interest in a just solution of the Kurdish problem. The fate of Kurdistan was never regarded in the Kremlin-or in London or Washington-to be a humanitarian issue, access to the oil fields in Kurdistan appeared to be the decisive motive in the cynical policy of both the East and the West." The tragedy of Barzani and the Kurdish people is "that the interests of the East and the West-and to a certain extent of the Arab States and Iran-are to preserve the Kurds as a deterrent force in the region, a pawn in the interregional struggle among Turkey, Iraq, and Iran." As a "reasonable solution for the Kurds" Sudoplatov envisaged "international guarantees of limited autonomy", but "no one in the West or the Arabic states wants the Kurds to control the Mosul oil fields in an independent Kurdish republic", he concluded as long as a quarter of a century ago. Mustafa Barzani was characterized by the late Soviet spy-master as "real feudal lord" and as "shrewd politician and military commander". Barzani was "intelligent enough to understand that the future of the Kurds depended on their capacity to manipulate the interests of the superpowers in the Middle East'

\footnotetext{
${ }^{30}$ Mikhail Suslov (1902-1982), leading Soviet Communist ideologue and power broker from the 1950s until his death. The Americans followed Soviet-Barzani contacts closely in the 1960s, see for example the CIA cable 50X1, E.O.13526, dated 21 August 1965, excerpts: 1) About 1 August 1963 four Soviet military officers arrived at Barzani headquarters. The Soviets talked with Barzani at Mastan, a small village between Rawanduz and the Iranian border, and told Barzani and several of his men that they should "be patient a little longer because soon someone else will come and fight for you. [...]" 2) Barzani has been receiving small arms, ammunition, and foodstuffs by air from the Soviets. 3) There are 19 Soviet wives of Barzani Kurds with their 20 to 25 children in Barzani headquarters."

(https://www.archives.gov/files/declassification/iscap/pdf/2012-029-doc2.pdf, accessed 20 May 2018).
} 
(Sudoplatov \& Sudoplatov, 1994-1995: pp. 259-260, 263-264). His final balance sheet was as plain and unsentimental as his other observations: He had, he said, successfully "contracted" Mustafa Barzani, but Moscow failed "to turn the Kurds into our strategic ally to control who ruled lraq" (Sudoplatov \& Sudoplatov, 1994-1995: p. 264). ${ }^{31}$

After Sudoplatov the late KGB archivist Vasili Nikitich Mitrokhin, who defected to the UK in 1992, published a few additional remarks on Mustafa Barzani. Mitrokhin summarized: "the KGB maintained covert contact in northern Iraq with the leader of the Kurdistan Democratic Party (KDP), Mullah Mustafa Barzani (codenamed RAIS), who had spent over a decade in exile in the Soviet Union after the Second World War. From 1968 to 1972 the KGB carried out twenty-three operations to pass funds to Barzani. In 1973, after a series of clashes with Iraqi forces, Barzani publicly accused the Baghdad government of duplicity and double-dealing. Forced to choose between the Ba'th regime and the Kurds, Moscow opted for the Ba' th." (Mitrokhin, 2005: II, 175). ${ }^{32}$

10) Mustafa Barzani no "spy"

The former Soviet foreign security archivist Vasili Nikitich Mitrokhin uses in his collection of KGB files the term “RAIS" for Mustafa Barzani only once. His source also remains the only one known that documents " $R A I S$ " as a "codename" for the late Iraqi Kurdish leader. No other available Soviet sources have so far come to light that provide codenames for contacts of the Kremlin to Barzani (or indeed to any other Kurdish leader). Pawel Sudoplatov, the former head of KGB special task operations, does not mention any codename for Barzani in his publications, and it is unlikely that he would have had no knowledge of one. Yet, both confirm accordingly that Mustafa Barzani had cooperated with the Soviets, that he maintained covert contacts, who were obviously in some form contracted, that each side pursued different, finally incompatible goals, and that Barzani also accepted financial support in cash, but they did never call him a "spy". That is why from the single short one-time description alone of the Soviet archivist Vasili Mitrokhin, it cannot be conclusively concluded that Mustafa Barzani would indeed have been a Kremlin "spy". There are a number of good reasons that make such an assumption unconvincing. For one, the term "Rais" was in the past commonly used for all kinds of leading personalities at that times. For example, when Mustafa Barzani served as dominant Iraqi Kurdish military commander in the Soviet-supported "Kurdish Republic of Mahabad", its leader, Qazi Mohammad, started in May 1946 efforts to change the titles of his regional government members from "wazir" (minister) to "rais", translated ${ }^{31}$ Entire quote l.c.: "When I was in jail, I wrote proposals for contacting Barzani when the situation in the Middle East was aggravated in 1963. I was informed that my proposals were accepted, and the Kurds were supplied with ammunition and weapons to defend their areas against punishment expeditions by the Iraqi army. However, our attempts to turn the Kurds into our strategic ally to controi who ruled lraq ended in failure."

${ }^{32}$ Cf. recently: Mirsky, 2003: "Incidentally, many Iraqi Kurds, although disappointed with Moscow's pro-Saddam policy, still remember with gratitude those Soviet specialists who provided assistance to the Kurdish regions in the 1970 s and the early 1980 s.": http://eng.globalaffairs.ru/number/n_636 (accessed 1st Dec. 2017). 
by Roosevelt, 1947: p. 261 in good Persian (Iranian) tradition simply as "chief". The reason for that subtle differentiation was that Qazi Mohmmad wanted to calm down escalating tensions with the central power in Teheran and confirm readiness to keep his self-governed autonomous "Republic" within the constitutional sovereignty and boundaries of the then Iranian monarchy. This indicates that the term "rais" had a long-standing tradition of a general usage and was not tailored to one specific person only like Mustafa Barzani. Secondly, Mustafa Barzani accepted also financial help from various foreign countries he cooperated with (including Israel) in order to achieve national Kurdish rights, but numerous eyewitnesses confirm that he used that money as a rule chiefly for the KDP-I movement, did not enrich himself and lived a fairly simple life. Three, there exists furthermore a broad consensus among scholars that Mustafa Barzani was ideologically never a communist and that even some ten years of exile in the USSR did not convert him to one. Four, as already explained in this short analysis, Barzani evidently maintained throughout his life numerous contacts to virtually all neighboring states and also to the superpowers of his time in order to achieve national Kurdish rights (and maintain tribal influence). And in this regard, it was common practice as early as in the 1940s when Mustafa Barzani started his international career to discredit political and military opponents as "spys". Roosevelt and Eagleton described for instance in detail how the Soviets back then used the term "spy" to discredit unwanted rivals of their chosen political leader Qazi Mohammed for the Mahabad Republic, such as the respected Sufi Sheikh Abdullah Effendi Gilani or Mustafa Barzani as "British spies". Conversely, the Americans distrusted Barzani for quite a long time after WWII, regarded him as a communist, called him "Red Mullah" and painted him as an enemy of the US. ${ }^{33}$ American scientists are only recently correcting this impression, notably: Gibson, 2015: p. 9, 11: "Washington had failed to recognize that Barzani was not a Soviet agent or that Soviet attempts at indoctrinating him in communist ideology had failed", "[he] did not actually threaten American interests and could have been a powerful ally." However, the most credible explanation why the Kurdish leaders had already dismissed by the end of WWII Soviet accusa-

\footnotetext{
${ }^{33}$ See for example the collection of U.S. State Department documents:United States Department o1 Statel Foreign relations of the United States, 1948. The Near East, South Asia, and Africa (in two parts), (1948), Iran pp. 88-201, online: http://digicoll.library.wisc.edu/cgi-bin/FRUS/FRUS-idx? type $=$ div\&did=FRUS.FRUS1948v05p1.i0009\&isize=text $($ accessed 10 March 2018): pp. 104, 130, 148. American scholars labeled also the pan-Kurdish nationalist movement "Khoyboun", which was founded in the 1920s by the Bedir Khan's in Lebanon as "the most dangerous" because of USSR support: Westermann, 1946: p. 686: "the Kurdish movement for Khoiboun is the most dangerous or all the troubles which now beset the Middle East, because of the support which it has from Soviet Russia". However, the prevailing post-WWII American view of a Soviet supported Kurdish nationalism was not necessarily shared by Europeans at the time. One example: The Scottish born British army Colonel William Graham Elphinston (1886-1952) wrote also in 1946 in sharp contrast: "the statesmen of the United Nations are unlikely to give high priority to the Kurdish problem. Nevertheless, if the principles of the Atlantic Charter are to be applied, the Kurds have as much right as any other people to share in the Four Freedoms. [...] The Kurdish Nationalists are not unreasonable. They simply desire to be allowed to live as Kurds, speak the Kurdish language, read and publish books and newspapers in that language and not to be assimilated as Arabs, Persians or Turks" (EIphinston, 1946: p. 91).
} 
tions, expressed by the Azerbaijan communist leader Baghierov, that Mustafa Barzani was "a British spy", was already offered by William Eagleton Jr. in 1963. He summed up conclusively (Eagleton, 1963: p. 46): The Kurdish leaders "were firmly convinced that a Kurd could only be a Kurd and that outside connexions or commitments would melt away once Kurdish goals were attained."

11) Conclusions: Soviet-Kurd-Relations

The Soviet Union had offered the Kurds for the first time in the 1940s to support the formation of a greater Kurdistan comprising Kurdish areas in Turkey, Iraq and Iran. The proposal was later downsized to a Kurdish independent state in Iraq in close cooperation with Kurdish autonomous regions in Turkey and Iran. These plans were obviously authorized by Soviet leader Joseph Stalin personally and introduced and followed up by the communist chief of the Azerbaijan SSR, 1932-1953, Jafar Baghirov. The decision to create a greater Soviet "democratic" Kurdistan was taken by the "Central Committee" in its offices on Staraya Ploshchad in Moscow (Sudoplatov \& Sudoplatov, 1994-1995: p. 261). No timeframe is given, no original source is published. Given the cited description of the so-called Baku process by Roosevelt, Eagleton and Sudoplatov, it can be assumed that such plans had been worked out in the Kremlin after $\mathrm{Na}$ zi-Germany invaded the Soviet Union in 1941, and attitudes changed among Soviet contacts between 1944-1945 to grant (Iranian) Kurds not only autonomy but self-rule as a (SSR) “Republic". The Kremlin had connected both statehood (“SSR Republic") and non-state (regional autonomy) concepts specifically to two equally dynamic Kurdish leaders of completely different backgrounds: to the bourgeois urban intellectual religious judge Qazi Mohammed from Mahabad, Iran, and the rural conservative feudal Iraqi tribal leader Mustafa Barzani from Barzan in Iraq. In both cases, the Soviets finally withdrew their initiated support, mainly because they could not use them as Kurdish proxies to achieve geostrategic goals (like oil-concessions and influence over central powers in Teheran and Baghdad). And in the specific case of Mustafa Barzani, because the Soviets came to the conclusion that he would not be able and willing to implement "Democracy" and share power for current relations between Russia and the [Iraqi] Kurds see i.a. Yefremenko, 2017 or Zhdannikov, 2017 \& 2018).

\section{Israel - Shah-Iran - USA - Kurds}

The United States supported the Iranian Shah Mohammed Reza Pahlavi (1919-1980) end of the 1960s and in the 1970s against policies of the emerging Ba'ath regime in Iraq under the leadership at the time of Ahmed Hassan al-Bakr (1914-1982) and Saddam Hussein (1937-2006). Both the U.S. and the Shah-Iran used Kurds temporarily as proxies to weaken the Ba'athist regime in Iraq. They dumped the Iraqi Kurds harshly after Iraq had conceded Iran half of the Shatt al-Arab (Arvand Rud) free waterway to the Gulf. Israel backed both U.S. and Shah-Iranian policies and also supported the Iraqi Kurds in their struggle for autonomy from bases in Iranian but followed an own pro-Kurdish geostrategic 
agenda. Details of this so-called "Israel Kurds Connection" via Shah Iran in key words:

Historical Background: Keywords. Israel and the Kurds.

Israel actively supported the Iraqi Kurds ${ }^{34}$ in the 1960s and 1970s through the then Shah-Iran. ${ }^{35}$ Main motives of Israel were: "Israeli military advisers trained Kurdish guerrillas as a way to reduce the potential military threat Iraq presented to the Jewish state and also to help Iraqi Jews escape to Israep' (Gunter, 1994: p. 470). The Iraqi army, especially in the 1967 Six-Day War, was "tied to a 'second front in Kurdish areas" (Orland, 1997: FAZ, 07.04.1997, p. 9: "im Kurdengebiet an eine ' $z$ weite Front' gebunden"). Contacts with Israel Kurds go back to the 1950s, were intensified in 1963 and in 1965-1975 ended in an operation that was codenamed "Marvad" (carpet) (Gunter, 1994: p. 470). In the mid-1960s, these contacts from Israel were established by Arie (Aryeh) "Lowa" Eliav (1921-2010), born in Moscow, who emigrated in 1924 with his family in the British Mandate Palestine (granted by the Treaty of San Remo 1920: Hennerbichler, 2004: pp. 410-420), later distinguished himself as leading social-democratically oriented politician and Middle East peace pioneer, who was a member of the Knesset from 1965-1969 and 1988-1992 and also held ministerial posts on several occasions (Hennerbichler, 2004: p. 577 et seqq.). Among other things, Eliav contributed significantly to the fact that in the mid-1960s Israel set up a field hospital for Kurds in northwestern Iran near the Iraqi border and also operated it with a (changing) staff of doctors. After the Six-Day War in 1967 Yaakov Nimrodi (b. 1926 in Baghdad) played another leading role. Nimrodi then served as influential military attaché in Israel's unofficial embassy in Tehran. All in all, Israel provided the Kurds with humanitarian aid as well as "money, arms, and instructors', as former conservative Prime Minister Menachem Begin (1913-1992) disclosed in $1980 .{ }^{36}$ Israel sent "sophisticated weapons through Iran, particularly anti-tank and anti-aircraft equipment, accompanied by instructors" (Jawad, 1981: p. 303). The Israeli “Mossad" and the Iranian "Savak" also helped Mustafa Barzani to set up the (KDP) security apparatus "Parastin", which was founded in 1966. ${ }^{37}$ Some (Barzani) Kurds also received military training in Israel (Jawad, 1981: 1.c.). Mustafa Barzani visited Israel twice after the Six-Day War in September 1967 and a few weeks before the outbreak of the Yom Kipur War in 1973

\footnotetext{
${ }^{34}$ Minasian, 2007: p. 23 quotes a former Mossad employee, according to which Israel has always supported Kurds in Iraq only (from NW Iranian territories), but never those in Iran itself or in Turkey: "According to a former senior Mossad official Eliezer Tsafrir, Israel had military advisers at the headquarters of Mulla Mustafa Barzani in 1963-1975, trained and supplied the Kurdish units with fire arms, field and anti-aircraft artillery. The US also participated in this campaign [29]. Israel spent tens of millions of dollars on the support of the Kurds, supplying them via Iran, which pursued its own goals in Iraq and had close ties with Israel up until 1979. However, according to Eliezer Tsafrir's testimony, Israel never supported the Turkish Kurds in their war against Turkey or the Iranian Kurds under the Shah [29].” (Ftn. 29 = Reuters, 21.02.1999).

${ }^{35}$ Anderson, 1972: p. B7; Morris, 1980: p. 11; Ghareeb, 1981: p. 61; Jawad, 1981: pp. 287-288; Raviv \& Melman, 1990: p. 21 \& 82; Black \& Morris, 1991: pp. 184-185 \& 327-330; Cockburn, 1991: pp. 104-105; Gunter, 1994: pp. 470-471; Katz, 1994: p. 175; Nakdimon, 1996; Bengio, 1998a: pp. 32-41; Bengio, 1998b: pp. 115-116, 120, 233 n. 32 \&33; Hennerbichler, 2004: pp. 577-586; Minasian, 2007: pp. 15-32.
} 
(Gunter, 1994: pp. 470-471). Strategically, two military successes are attributed to the Iraqi Kurds by military aid from Israel from the northwest of Shah Iran: the victory of Kurdish "Peshmerga" against Iraqi forces at Hindarin mountain in May 1966 and the effective grenade launcher attack on the Kirkuk oil refineries in March $1969 .{ }^{38}$ In both cases Israeli military advisers were apparently directly involved. The attacks on Kirkuk ultimately contributed significantly to the fact that Iraqi Kurds were granted in 1970 a first autonomy agreement by the then Baath regime in Baghdad. This agreement still forms the basis for the current self-government of the autonomous Kurdistan Region of Iraq (Gunter, 1994: pp. 470-471; 20112: pp. 147-148; Hennerbichler, 2004: pp. 552-553). The Israelis ceased military cooperation with the (Iraqi) Kurds when they could no longer operate out of Shah Iran.

This commitment of Israel to self-determination of the (Iraqi) Kurds in the 1960 s and 1970s is judged differently in Israel today, although distinctly positively, but in details also rather skeptical. For the latter exampli gratia: $\mathrm{Na}$ chum Orland accused Israel in an analysis in 1997: "Even Israel was one of those states that exploited the Kurdish problem and had no interest in a satisfactory solution within the framework of the Iraqi state." ${ }^{39}$ Furthermore, in Israel was never really understood that Mustafa Barzani in no way wanted to tear down the last bridges "to the Iraqi people" and that he had tried to the last, "to arrive [even] with Baghdad to a mode vivendi", Orland added. He also credited Barzani indirectly with not having implemented "ludicrous plans" ("haarsträubende Pläne") by Israeli military advisors to "destroy dams in Iraq with Kurdish aid and cause the deaths of thousands upon thousands of people or paralyze Iraq's oil industry". Even "the use of non-conventional weapons" had been considered. These plans would have been concocted by Israeli military advisors who later represented parties and movements in the Knesset that propagated "the displacements of Arabs out of Israel as [political] aim", Na-

\footnotetext{
${ }^{36}$ Citing Jason Morris, Begin Airs Secret Israeli Aid to Kurds as Reminder for Iraqis, The Christian Science Monitor, 6 October 1980, p. 11. Menachem Begin's longtime chief of press, Schlomo Nakdimon, published in 1996 a historical review of this Israeli military mission for the Kurds under the title:" A hope that broke, the Israeli-Kurdish cooperation 1963-1975" (published in Hebrew by Jediot Acharonot and Chemed, Tel Aviv 1996. According to the American reporter Jack Anderson in 1972, who referredto CIA sources, Mustafa Barzani also received \$50,000 a month from an Israeli secret messenger: "Every month ... a secret Israeli envoy slips into the mountains in northern Iraq to deliver \$50,000 to Mulla Mustafa al-Barzani. ... The subsidy ensures Kurdish hostility against Iraq, whose government is militantly anti-Israel." (Israelis Infiltrate Arab Regimes. The Washington Post, 17 September 1972, p. B7).

${ }^{37}$ Ghareeb 1981: 133: "Both the Israeli Mossad and the Iranian Savak helped Barzani establish a sophisticated intelligence apparatus, Parastin [Security] ... to gather information on the Iraqi government and its armed forces."The KDP "Parastin" security apparatus is currently headed by the elder son of Masoud Barzani, Masrour.

${ }^{38}$ Riedel, 2017: “Against great odds, the Kurds drove the Iraqi army out of much of Kurdistan.": https://www.brookings.edu/blog/markaz/2017/11/02/masoud-barzani-and-the-roots-of-kurdish-dist rust-of-the-united-states. (accessed 2nd Nov. 2017).

${ }^{39}$ In German: "Auch Israel gehörte zu jenen Staaten, die das Kurdenproblem instrumentalisierten und an einer befriedigenden Lösung im Rahmen des irakischen Staates kein Interesse hatten" (Orland, 1997, Frankfurter Allgemeine Zeitung, no. 80, p. 9).
} 
chum Orland (l.c.) concluded.

\section{Iran Shia Crescent}

The so-called "ShiitelShia Crescent" is briefly mentioned here because it illustrates historical interests of Iran to extend its geostrategic influence from the Gulf to the Mediterranean. Currently, Israel is struggling in close cooperation with the U.S. administration of President Donald Trump and in ongoing negotiations with Russia to make sure that in the course of the war in Syria pro-Iranian proxy-militias will stay away from the Israeli borders particularly at the Golan frontlines an infinite deal more than one hundred kilometer. ${ }^{40}$ The outcome is open and undetermined.

Historical Background: Keywords: "Shiite Crescent" ("Shia Crescent"):

In the 16th century for the first time in its history, Iran's sphere of influence to its south was fundamentally constrained. In 1514, the Persian Safavids lost the decisive battle of Chaldiran, in today's NW Iran, against the Ottomans. Shah Ismail I (1487-1524), the founder of the Safavid dynasty, leader of the Shiite Safawiyya Order, and ancestor of Shia-Iran, was defeated by Sultan Selim I (1470-1520), the first caliph of the Ottomans, mainly thanks to superior artillery. ${ }^{41}$ Since then, Iran's areas of influence to the south have essentially been delimited by the Zagros mountains and the adjoining border river Shatt al-Arab as far as the Gulf. At the same time, Iranian rulers have up to the present day repeatedly proclaimed that territories west of the Zagros, including the Euphrates and Tigris, down to Yemen at the Gulf of Aden, are legitimate areas of Iranian interest and influence and have used the Kurds as proxies to expand their hegemony in Iraq and beyond. ${ }^{42}$ Most recently, Mohammad Reza Shah Pahlavi (1919-1980) dumped the Kurds, then led by Mustafa Barzani (1903-1979), in their struggle for autonomy in Iraq in 1975. In return, Iran had been granted from Iraq-then under Vice-President Saddam Hussein (1937-2006) - half of ${ }^{40}$ REUTERS:

https://www.reuters.com/article/us-mideast-crisis-syria-israel/israel-to-russia-assads-safe-from-us-b ut-iran-must-quit-syria-idUSKBN1K11RX; CNN:

https://edition.cnn.com/2018/05/09/middleeast/israel-rockets-syria/index.html; INDEPENDENT: https://www.independent.co.uk/news/world/middle-east/israel-iran-crisis-live-updates-war-golan-h eights-syria-air-strikes-nuclear-deal-netanyahu-rouhani-a8344501.html; JERUSALEM POST:

https://www.jpost.com/Israel-News/Netanyahu-tells-Putin-Israel-will-continue-to-act-against-Iran-i n-Syria-563022 (all accessed 28 July 2018).

${ }^{41}$ Hennerbichler, 2004: p. 373 et seq.; Agreement at foreign minister level 13 June 1975: UCDP: online: http://ucdp.uu.se/downloads/fullpeace/Iran-Iraq\%2019750613a.pdf; Border agreements chronologically: Exchange of letters Selim-Ismail 1514, online:

http://www.fas.nus.edu.sg/hist/eia/documents_archive/selim.php; Peace- and border-agreement Zuhab/Qasr-e Shirin 1639, confirmed 1746, 1823 and 1847, online:

http://www.fas.nus.edu.sg/hist/eia/documents_archive/zuhab.php; Protocolsof Teheran 1911 and Constantinople 1913: see: McLachlan, 2013: http://www.iranicaonline.org/articles/ boundaries-i; Iran-Iraq border treaties 1937, 1969 and 1975: cf. Kechichian, Joseph A., n.y.: EIr online: http://www.iranicaonline.org/articles/boundaries-iv; lately Gulf War 1990: Letters Saddam Hussein to Presidents of Iran: UNSC: online:

http://digitallibrary.un.org/record/96182/files/S_21528-EN.pdf?version=1 [all quoted online-sources accessed 20 January 2018]. 
the Shatt Al Arab river, a key waterway to the Gulf. ${ }^{43}$ Up to then the border had for many years run along the Iranian north shore. The Iraqi Kurds had previously, from 1970 to 1974, attained limited regional autonomy mainly thanks to temporary aid from the USA, Iran when it was ruled by the Shah, and Israel, which backed them in launching military attacks on the Kirkuk oil center, thus increasing pressure on the then Ba'ath regime in Baghdad to grant Iraqi Kurds self-government.

\section{Leadership Claim of Barzanis}

The Barzani family is for the most part dominating Iraqi Kurdish politics since 1946, temporarily halfway in power-sharing arrangements with the Patriotic Union of Kurdistan PUK. A truly Western model of democratic majority rule never evolved in Iraqi Kurdistan until today. In the following chapter it is intended to explain why this is the case.

\section{Historical Background: Keywords. Leadership claim of Barzanis.}

The KDP-Iraq has been led since its foundation ${ }^{44}$ in 1946 by the Barzani family. Mullah Mustafa Barzani was elected President of the "Kurdistan Democratic Party of Iraq" (KDP-Iraq) at its formal foundation on August, 16, 1946 in Baghdad in absence during Barzani's exile in Iran. Mustafa Barzani was KDP-Iraq ${ }^{42}$ Mustafa, 2016: Iran's Role in the Kurdistan Region. Al Jazeera Centre for Studies, online: http://studies.aljazeera.net/en/reports/2016/04/160420105055207.html. See also: Katzman, 2018

${ }^{43}$ Treaty 1975, UN-Registration-no. 14905, IRAN and IRAQ, Agreement concerning the rules governing navigation on the Shatt al'Arab (with exchanges of letters). Signed at Baghdad on 26 December 1975, online: https://treaties.un.org/doc/Publication/UNTS/Volume\%201017/volume-1017-I-14905-English.pdf (accessed 05 January 2018).

${ }^{44}$ The formation of modern Kurdish parties in Iraq, Iran and Turkey was a long process. They evolved since the 1920s over decades out of inter-communal consultations between leading Kurdish tribal chiefs and intellectuals of their time. None of these modern parties was exclusively founded by one specific single Kurdish personality alone (Hennerbichler, 2004: pp. 477-479, 510-511, 520-522). Efforts to unite various Kurdish movements reached a peak in 1944-1946 in the course of the Mahabad "Republic's" foundation (cf. the following description by Eagleton, 1963: p. 36). In March 1944 the Iranian "Komala" sent a delegate (Mohammed Amin Shafari) to Kirkuk in Iraq to discuss mutual aid and future plans with representatives of the "Hiwa" (hope) Party. "Hiwa" was established in 1938 mainly by Rafiq Hilmi (1898-1960), a Kurdish historian, writer and politicican from Sulaimaniyah, in the private house in Kirkuk of Amin Rawenduzy, a colonel in the Iraqi army (verbal conversation by his son Wiriya Rawenduzy, 1929-2011, the late doyen of the Kurds in Austria). They agreed on a pact. "Hiwa" was clandestine and had no specific party program. In early summer 1944 members of the Sulaimaniya branch of the "Hiwa" party paid a return visit to "Komala" and confirmed their pact. During the next year and a half Hamza Abdullah from Iraq, Qadri Beg from Syria, and Qazi Mullah Wahab from Turkey met Kurdish leaders in Mahabad and talked about autonomy options. In August 1944 Kurdish leaders from Turkey, Iraq and Iran met at Mount Dalanpar at the three-angel frontier of their countries and signed the pact "Peman I Se Senur" ("Pact of the Three Borders") for mutual support of a greater Kurdistan. Iranian Kurds were represented by Qasim Qaderi of the "Komala" from Mahabad. From Iraq came Skeikh Obaidullah of Zero. Turkey was represented by Qazi Mulla Wahab. The Kurdish Society in Beirut, dominated by the Bedr Khan family, contributed a map which defined geographically a greater Kurdistan. The Society consulted a number of international experts on the Kurdish question at the time and wanted to show the geographically largest possible Kurdistan, as Eagleton noted. Its extent comprised Kurdish inhabited areas from south-eastern Anatolia to the Gulf. Further reading (selection): Laqueur, 1956: pp. 221-232; Arfa, 1966: p. 124; Stansfield \& Anderson, 2009: pp. 65-66; Sluglett \& Sluglett, 2003: p. 29; Jawaideh, 2006: pp. 230-242; McDowall, 2007: p. 295; Aziz, 2011: p. 67; Amarilyo, 2014: p. 77. 
President until his death (he died March 1, 1979 in Washington, D.C., USA). However, the "Democratic Party of Kurdistan Iraq" was established only after two attempts. ${ }^{45}$ As early as mid-February 1946 Mustafa Barzani, together with Hamza Abdullah, launched a "Democratic Party of Kurdistan Iraq" in Oshnaviyeh, close to the Iranian border with Iraq. Hamza Abdullah was "a pliant leftist" (Anderson \& Stansfield, 2004: p. 165) lawyer from Zakho in northern Iraqi Kurdistan, who had studied in Baghdad. The reason for forming this party was that Hamza Abdullah operated at the time as Barzani's contact man with Soviet representatives in Mahabad. They put mounting pressure on them to launch in Iran an Iraqi version of a Kurdish Democratic Party as well, modelled on the KDP-Iran headed by Qazi Mohammed. Hamza Abdullah yielded to the Soviet demands and told Barzani he agreed and subsequently proclaimed a KDP-Iraq in Oshnaviyeh, Iran. Qazi Mohammed denounced outright the foundation of a separate KDP-Iraq in Iran as an effort to weaken and split the Mahabad Republican movement, and called on Barzani, appealing to him to act only in concert and urged him to cancel a KDP-Iraq in exile in Iran. Barzani complied and sent Hamza Abdullah, at the end of March 1946, back to Iraq. Abdulla left Barzani disappointed. A few months later, the KDP-Iraq was successfully and sustainably launched in Baghdad on 16 August 1946, this time chiefly with the cooperation between Mustafa Barzani and Ibrahim Ahmed (1914-2000) ${ }^{46}$ the father of the political left in Iraqi Kurdistan. He was born in Sulaimaniyah, the traditional stronghold of leftist groups in the south east-east. Ahmed, a lawyer, poet, and politician, was a veteran member of the Iranian "Komala" movement " $J K$ ", which had established a Sulaimaniya branch under a version of the "KJ" party label. Simultaneously, Ahmed also acted as representative of the KDP-Iran in Iraq and had met Qazi Mohammed in Mahabad.

Both Ibrahim Ahmed and Qazi Mohammed wanted an urban, left-dominated political Kurdish International striving for a greater Kurdistan within the borders of existing states. Its center was supposed to between cities in the most highly developed parts of Kurdistan, and regular meetings should foster national cohesion. Mustafa Barzani opposed this idea. Ahmed suggested Barzani should join the KDP-Iran and become the president of its Iraqi branch. Barzani rejected this too. He was determined to found a Barzani tribal dominant, a rural conservative national Iraqi Kurdish party incorporating a subordinate political left wing.

When Hamza Abdulla left Oshnavieh and Mahabad for Baghdad in February 1946, Mustafa Barzani instructed him to bring a letter to Ibrahim Ahmed in Sulaimaniyah, Iraq. It contained proposals for the foundation of the KDP-Iraq in Iraq. Barzani insisted on establishing a separate KDP Iraq and claimed to be elected as its president. Ibrahim Ahmed declined both demands but agreed to accompany Hamza Abdullah to Baghdad and participate in the establishment of

${ }^{45}$ Sources: Research by Abdol-Hamid Hosseini, based on eyewitness accounts at the time.

${ }^{46}$ Eyewitness account by Ibrahim Ahmed in his house in British exile in Surrey, UK, 1982-1983. He was talking to the author of this brief analysis in the presence of Omar Sheikhmous, veteran Kurdish intellectual and co-founder of the PUK, who also translated. 
the KDP Iraq as an observer, representing also the KDP Iran. Finally, the founder members ${ }^{47}$ met secretly on August 16, 1946 at the Baghdad home of the Kurdish poet Ali Hamdi, performed the act of foundation, and elected Mustafa Barzani in absentia despite his exile in Iran as party president and Hamza Abdulla as first Secretary General. Ibrahim Ahmed and his followers joined the KDP-Iraq in May 1947 after the collapse of the Mahabad "Republic" and the hanging of President Qazi Mohammed, arguing that Iraqi Kurdistan emerged subsequently as the new center of the Kurdish national movement.

Months before, presumably between December 1946 and the beginning of 1947, Barzani ordered Hamza Abdullah to take another letter to Ibrahim Ahmed to Sulaimaniyah. In this letter Barzani asked the then Iraqi government to grant him and his tribal members in exile in Iran to return to Iraq freely and to receive amnesty. Baghdad refused. Barzani had hoped that his chances to be allowed to return to Iraqi Kurdistan would improve if Baghdad could be convinced that he was not only an influential tribal leader to be reckoned with but also an arising influential Iraqi Kurdish party chief with a broad backing by the population. After he was turned down, he and close tribal members battled their way into the Soviet Union where they arrived in June 1947.

From 1947, Mustafa Barzani lived for some 11 years with family tribe members in exile in the Soviet Union, returning in 1958 to Iraq. During that time, Barzani's closest associates lost control of the party to Ibrahim Ahmed, who exerted a major influence on the Kurdish movement in Iraq. ${ }^{48}$ Ibrahim Ahmed was elected as Secretary General at the second party congress in the summer of 1951. He had just been released from prison. The faction loyal to Barzani over several years existed as a separate organization; it had closer contacts with the Iraqi communists than the "officiaP' KDP (Van Bruinessen 1986, MER 141). In 1957 the two factions reunited. At KDP-I's third congress in January 1953 the party was substantially reorganized. Its name was changed from "Kurdish Democratic Party" to "Kurdistan Democratic Party". This indicated an opening up of the party to all people in Iraqi Kurdistan regardless of ethnic identity and was seen a gesture towards civic nationalism. Hamza Abdulla was formally expelled for divisive tactics within the party. He temporarily formed the alternative "Kurdistan Democratic Party - Progressive Front” but return to the KDP in 1956.

Following his return from the Soviet Union in 1958, Mulla Mustafa Barzani took over the party leadership. Soon after the KDP-I decisively split in 1964. Barzani expelled the entire left. He accused them of rebellion. They in turn denounced him for being incapable of accepting democratic majority rule. ${ }^{49}$ As a result, leftist party politburo members, headed by Ibrahim Ahmed and Jalal Ta-

${ }^{47}$ Indications about their number vary from around 10 to 30 . Hamza Abdullah was wanted by the police at the time.

${ }^{48}$ Van Bruinessen, Martin (1986). Major Kurdish Organizations in Iraq, MER (Middle East Research and Information Project) 141 - Hidden Wars, vol. 16, July/August 1986, quoted online: https://www.merip.org/mer/mer141/major-kurdish-organizations-iran (accessed 2 June 2018). Similar assessment by the Kurdish Institute in Paris: Fondation-Institut kurde de Paris, Timeline: Iraqi Kurdistan, 1951 online:

https://www.institutkurde.org/info/timeline-iraqi-kurdistan-1172069593.html. 
labani, held an alternative party congress in Ranya northwest of Sulaimaniyah. In early 1965 Jalal Talabani fled to Iran with some 700 followers. They were provided with settlements near Hamadan. At the beginning of 1966 all of them returned to Iraq. The motive for this was that Iraq's President Abdul Rahman Arif (1916-2007, in office 16 April 1966 to 17 July 1968) had initiated a law of administrative decentralization in Iraq which took effect on 28 June 1966. Jalal Talaba$\mathrm{ni}$, together with Ibrahim Ahmed, accepted cooperation with Baghdad and were authorized to run a regional self-rule administration in Sulaimaniyah. Its headquarter was in Bakrajo, then a suburb, now a municipal district of Sulaimaniyah. Their collaboration was heavily criticized at the time by opponents. Its main achievement was the foundation of the Sulaimani University UoS in 1968, now with about 25,000 students, eight faculties, and two colleges, one of the greatest universities in Iraqi Kurdistan. This local Kurdish self-governed administration in Sulaimaniyah lasted from 1966 to 1970 . When the regional autonomy manifest for the Iraqi Kurds was proclaimed on 11 March 1970 by the new Iraqi Ba'ath Regime under President Ahmed Hassan al-Bakr (1914-1982) and Saddam Hussein (1979-2003), then Vice-President, Jalal Talabani went into exile in Damascus from 1970-1975. Ibrahim Ahmed returned to the leadership of the KDP-I under Mustafa Barzani, resumed his post as Secretary General, ${ }^{50}$ and had his headquarter in Haji Omeran, near the border with Iran.

In 1967-1968 the Barzanis and Mullah Mustafa had been personally accused of having helped the Iranian army to track down and slay "Peshmerga" of the KDP-Iran. ${ }^{51}$ The latter had launched a two-year armed struggle for Kurdish autonomy rights in Iran against the Shah regime, achieved temporary local success, and could not be crushed by the Iranian army. Eventually, special commandos of the so-called Iranian border gendarmerie managed to surround and kill them. Their corpses were allegedly mutilated and exhibited for days in the streets of Iranian border towns. Mustafa Barzani was blamed for ordering his own "Peshmerga" to prevent the resurgent Iranian Kurdish fighters from escaping to Iraq

${ }^{49}$ Terms such as "chauvinist", "fascist", "reactionist" or "fanatic" were current at that time with both sides when referring to the other (Bengio, 1998b: pp. 115-116, 120, 233 n. 32 \& 33). See also Gunter, 1994, 2011² and 2018.

${ }^{50}$ KDP-I party President Mustafa Barzani did not talk with him for a year or so, Ibrahim Ahmed recalled in 1982 (personal communication).

${ }^{51}$ Ghassemlou \& Hessami, 1971: pp. 88-89 contains a list of 25 KDP-Iran "Peshmerga" who were killed, among them more than ten of whom Mustafa Barzani and his followers are accused that they had them either personally slayed or extradited to Iranian authorities. - A very critical assessment is also published by Pelletiere, 2016: p. 22 and $34 \mathrm{ftn} .77$ about the role of the Barzanis at the time: "the Barzanis [...] were accorded more or less permanent asylum in Iran. Barzani and his peshmergas remained there and were in residence when four years later the Shah was overthrown by Khomeini. And the tribe's course of action after Khomeini s coming to power is interesting. [...] Here it's worth noting (because it bears on the claim that the Barzani tribe formed the vanguard ot Kurdish nationalism) that in the $1980 \mathrm{~s}$, right after the Islamic Revolution took place in Iran, the Barzanis, who were resident in Iran at the time-having been driven into exile after the 1975 Barzani revolt-aligned themselves with the Khomeiniists. Their first duty was to crush a movement o1 Iranian Kurdish autonomy led by the Iranian Kurdish Democratic Party (IKDP) under the leadership of Abdul Rahman Ghassemlou, which the Barzanis did (crushed it, that is). Ghassemlou was later assassinated by Iran's Revolutionary Guard, which sought him out in Europe where he had sought refuge." Further reading: Ghassemlou, 1980, 1980-1981 and 1988. 
and had also had some of them killed. All in all, more than 100 KDP-Iran "Peshmerga" lost their lives.

Following the suppression of the Iraqi Kurdish struggle for autonomy in 1975, Masoud Barzani, along with his half-brother Idris, temporarily led the KDP Iraq out of exile in Iran until the death of their father Mustafa Barzani in 1979. In the wake of the so-called Algiers Agreement of March 6, 1975, between Shah Reza Pahlevi and Iraq's Vice President Saddam Hussein, the Shah-Iran had abandoned the Iraqi Kurds in collusion with the USA, who at the time were guided by a hard-liner "Realpolitik" of Foreign Secretary Henry Kissinger against Kurds, and when the Iraqi army soon after had crushed their military struggle for regional self-rule, hundreds of thousands Iraqi Kurds fled to Iran and were granted transitional refuge there. Mustafa Barzani and his family were allowed special exile accommodations in Karaj northwest of the capital Tehran. He later emigrated to the US for cancer treatment and died on March 1, 1979 at a hospital in Washington. The body was then flown to Iran, first buried in Oshnovieh in the northwest, and then entombed in 1993 in his native Barzan, Iraqi Kurdistan. In November 1979, the KDP elected a new leadership at the first party congress following the death of Mustafa Barzani, in Zewa. It came to an éclat and a breakup. ${ }^{52}$ The then influential party secretary-general, Mohammed Mahmood Abdul "Sami" Rahman, tried to take over the KDP and push back the duo leadership of Masoud and Idris Barzani. "Sami" Rahman was the first leading Iraqi Kurdish politician who did not come from the Barzani family (or from the closely related Zebaris) and who intended to break with the tradition that the Barzanis led the KDP-Iraq continuously since foundation. Rahman failed, was handed over to Iranian security authorities, detained for about half a year in Evin Prison in Tehran, and released only after months of international interventions. Among the international personalities, who campaigned for his release, was the later Austrian Federal President Dr. Heinz Fischer. Soon after he was freed "Sami" Rahman initially went to Damascus into exile, founded smaller, social-democratic oriented parties following European models, but achieved no breakthrough, eventually returned to the KDP-Iraq, served most recently as deputy party chairman and since 2003 also as vice-premier in the fourth KRG Regional government ${ }^{53}$ in Erbil under Nechirvan Idris Barzani, and was finally killed in early February 2004 in a devastating suicide bombing attack in Erbil attributed to militant Islamists. ${ }^{54}$ Idris Barzani, the half-brother of Masoud, had already died in late January 1987 at the age of 43 at his home in exile in Karaj in Iran, under odd circumstances that have not yet been clarified completely. As cause of death doctors diagnosed heart failure. An autopsy was not performed. Since then, Masoud Barzani has leaded the KDP Iraq as party president. Therefore, the KDP-Iraq was from 1975-1979 under his co-leadership and is managed since 1987 by him single-handedly. A son of Idris Barzani, Nechirvan, is cur-

\footnotetext{
${ }^{52}$ Hennerbichler, 2004: pp. 587-590.

${ }^{53}$ Hennerbichler, 2004: p. 73 et seqq. cf. also Pelletiere, 1991.

${ }^{54}$ Obituary, The Times, 26.02.2004:

https://www.thetimes.co.uk/article/sami-abdul-rahman-sz6jqn5xrrr (login necessary).
} 
rently acting KRG Regional Premier.

\section{Constitutional Crisis Iraq}

While the Federal Constitution of Iraq provides since 2005 a roadmap for an urgent solution of still dangerously unresolved open and disputed questions, both sides failed so far to mutually agree on lasting future compromises and implement them. There remains only one option on the negotiating table: either the legitimate representatives of the Iraqi Kurds and of the federal government in Baghdad resolve open disputed constitutional questions in direct negotiations or an atmosphere of confrontation will continue and could result in renewed military clashes any time in the future (Morris, Wirya, \& Ala'Aldeen, 2015).

Historical Background: Keywords: Continued constitutional dilemma Iraq

The constitution of the Federal Republic of Iraq of 2005 is very vaguely formulated as regards the borders of the Kurdistan region, as well as on Kirkuk and other "disputed areas". The official border of the Kurdistan region is still the so-called "Green Line", which was unilaterally established by the Iraqi army in 1991 as a truce-line after fighting against insurgent Kurds. This "Green Line" was defined in Article 53 (A) of the 2004 "Transitional Administrative Law (TAL)" as follows: "The Kurdistan Regional Government is recognized as the official government of the territories that were administered on 19 March 2003 in the jurisdictions of Dohuk, Arbil, Sulaimaniya, Kirkuk, Diyala, and Neneveh." ${ }^{55}$ Thus, it was legally decreed that the administrative boundaries of the Kurdistan Regional Government extend beyond the (then) three jurisdictions of Dohuk, Erbil, and Sulaimaniyah. However, TAL fails to identify which areas of the Kirkuk, Diyala, and Ninewa governorates, to which reference is also made, are included in this extended demarcation. There is no authoritative definition of the "Green Line" itself. Of vital significance is the fact that Kirkuk, qua city and governorate (along with the districts of Hawija, Dibis, Kirkuk and Daquq), is the only province defined in the 2005 constitution as "disputed" between the KRG and the federal government of Iraq in Baghdad. In the federal Iraqi legislation (for example, in the electoral law for the provincial elections in 2009, as well as in the national suffrage of 2010), several specific regulations were decreed for Kirkuk. By contrast, the draft of a Constitution of the Kurdistan Region (quoted in Kelly 2010: 774 et seq.) in Article 2.1 of the June 23, 2009 version, "Kirkuk" (in its constitutional entirety) is specifically designated as part of "Iraqi Kurdistan", but without naming specific (sub-)districts, although these were specified in the cases of Nineveh and Diyala. This is interpreted by the Iraqi Kurds as a claim on Kirkuk (see Kane, 2011: pp. 24-25). The opposing position of the Iraqi federal government was formulated by former Prime Minister Nuri al-Maliki in 2008: Kirkuk is a city that belongs to the federal government of Iraq, should be

${ }^{55}$ Iraq Constitution, 2005: https://web.archive.org/web/20161128152712/, http://www.iraqinationalitygov.iq/attach/iraqi_constitution.pdf, TAL:

http://www.cpa-iraq.org/government/TAL.html 
treated as a special case, and could become an independent region. ${ }^{56}$ In addition, the so-called autonomy agreement of March 1970 between the then leadership of the Iraqi Kurds under Mustafa Barzani (1903-1979) and the "Revolutionary Command Councip' (Bassireh, 2003: p. 58 et seqq.) under President Ahmad Hasan al-Bakr (1914-1982) and then Vice-President Saddam Hussein (1937-2006) in Baghdad, published on March 12 1970, as a 15-article "Manifesto" (Hennerbichler, 2004: p. 554), remains legally valid in Iraq to this day. It promised the Iraqi Kurds autonomy and administrative control in areas where they-de facto from 1970-1975-made up the majority of the population (cf. article 1 of the Manifesto). The 2005 Constitution contains, in the crucial Article 140, the essentially ambiguous wording "Kirkuk and other disputed territories", but also provides for a three-stage plan. Crucially this calls for the eventual status of Kirkuk, and its incorporation into the final administrative internal Iraqi borders to be determined by a process of normalization, a census and a conclusive referendum. A deadline was set for December 31, 2007, for its implementation. ${ }^{57}$ However, the 2005 constitution leaves key issues unresolved, including voter eligibility, jurisdiction boundaries, and referendum questions. Thus, to date, there remain considerable problems in implementing it, thanks to wording in the current 2005 constitution $^{58}$ which is susceptible to different interpretations. Moreover, because of irreconcilable conflicts of interest and objectives, as well as lack of willingness to compromise, all those involved and affected have been unable to agree on (still available) options for resolving them (see comments in the final section of this analysis). So, deadlines have not been met, nor have specific indications for dealing with these differences, set out in the constitution itself, been followed. ${ }^{59}$ In keywords:

Guidelines for the three-step plan are not specifically set out in Article 140 of the 2005 Constitution. Rather, this refers to Article 58 of the interim legal status of the "Transitional Administrative Law (TAL)", which was adopted in 2004 by the then Iraqi transitional government ("Iraqi Transitional Government" of the "Coalition Provisional Authority"). ${ }^{60}$ However, neither TAL 58 nor Article 140

56“Maliki: Kirkuk Belongs to the Iraqi Government," Zaman, 15 October 2008: "Kirkuk is a city that belongs to the federal government ... the only suitable solution, at this time, is to treat it as a speciai case, like being an independent region" (citing Kane, 2011: p. 52, ftn. 69).

57" Article 140: First: The executive authority shall undertake the necessary steps to complete the implementation of the requirements of all subparagraphs of Article 58 of the Transitional Administrative Law. Second: The responsibility placed upon the executive branch of the Iraqi Transitional Government stipulated in Article 58 of the Transitional Administrative Law shall extend and continue to the executive authority elected in accordance with this Constitution, provided that it accomplishes completely (normalization and census and concludes with a referendum in Kirkuk and other disputed territories to determine the will of their citizens), by a date not to exceed the 31 st of December 2007." http://www.wipo.int/wipolex/en/text.jsp?file_id=230000 (accessed 22 August 2018). ${ }^{58}$ Cf. MERI 2015: 17-22.

${ }^{59}$ Iraqi-Kurdish position: “The constitution set a December 31, 2007 deadline to complete all these steps. Nearly ten years later, no steps have been substantively executed.” (KRG GOV., 2017: p. 8). See also: KRG Ministry of Extra Regional Affairs (2007). Report on the Administrative Changes in Kirkuk and the Disputed Regions (pp. 1-99). http://perleman.org/files/articles/130508111135.pdf 
of the 2005 Constitution provides detailed guidelines on how to implement the stipulated three-step solution. Both are ambiguously phrased in such a way as to ensure that disunity and tensions among Kirkuk's ethnic groups are repeatedly inflamed. Paragraph (A) in TAL Article 58 refers to the "injustice" of politically-motivated forced ethnic relocation by the former Saddam Hussein regime and calls for this to be reversed and the original demographic nature of affected regions, notably that of Kirkuk, restored. The task of implementation was mainly assigned to the "Iraqi Property Claims Commission". For resettlement, a "reasonable period of time" was granted (A.1.). Resettlers were promised financial compensation from the state, and alternative land "nearby" (A.2), along with jobs (A.3). Those affected were guaranteed by A.4 the right to freely choose "national identity and ethnic affiliation”. Article TAL 58 (B) provided for recommendations of the then Transitional Government to the Iraqi Parliament to reverse the former regime's "manipulated and changed administrative boundaries for political ends". If there should be no agreement, there was a provision for intermediaries, in the last instance the UN Security Council. TAL 58 (C) determined a final "fair and transparent census" in the disputed areas, including Kirkuk. This solution should be based on the principle of justice and take in consideration "the will of the people of those territories".

Partial solutions up to now. Financial compensation for Arabs resettled from other areas of Iraq under the Saddam Hussein regime to leave Kirkuk voluntarily: ${ }^{61}$ Baghdad decided on March 29, 2007, to pay every Arab family 20 million Dinar (then around US $\$ 15,000$ ) and give those who volunteered to return to their original homes a piece of land. This regulation came into force immediately, a further decision of the Iraqi Parliament was not required. ${ }^{62}$ It is not known how many Arabs have accepted this compensation offer so far. According to MERI 2015: 17-18, a total of 120,320 compensation applications were filed by families subjected to forced displacement in 2007-2014; of these 61,466 would not receive any financial compensation. Of newly-settled Arabs, a total of 28,384 compensation applications are thought to have been submitted. Of these, only 5774 files could expect financial compensation. For Kirkuk alone, around 600 ${ }^{60}$ http://web.archive.org/web/20090423064920/http://www.cpa-iraq.org/government/TAL.html (accessed 15 January 2018). A brief note to available relevant UN-sources: The UNAMI (UN Assistance Mission in Iraq) 2009 provisional report on Kirkuk and other "disputed internal boundaries in northern Iraq" is currently (end of August 2018) not available online. See instead Knights \& Ali, 2010 and Knights \& Wahab, 2018. All other mentioned UN sources in this study are quoted from UNTC (United Nations Treaty Collection) (1975 \& 1976) and the UN digital library (1990).

${ }^{61}$ So-called" wafideen", Arabic for "newcomer", cf.: Human Rights Watch (Middle East): Genocide in Iraq, The Anfal Campaign against the Kurds, A Middle East Watch Report, Human Rights Watch, 1 July 1993: 1: Ba' this and Kurds [Kurdish Autonomy and Arabization]:

https://www.hrw.org/reports/1993/iraqanfal/ANFAL1.htm (cf. also HRW, 1991 \& 2006, all accessed 20 January 2018); Talabany, 1999: 11 et seqq. (III. Attempts to Arabize the Kirkuk Region): https://www.kurdipedia.org/files/books/2013/87924.PDF?ver=130286343280814632 （accessed 20 Jan. 2018).

${ }^{62}$ Reuters (Baghdad), 31st January 2007: Iraq to compensate Arabs o leave Kirkuk: https://www.reuters.com/article/us-iraq-kirkuk/iraq-to-compensate-arabs-to-leave-kirkuk-idUSKA R15688920070331 (accessed 17 January 2018). 
billion Iraqi Dinar would be required to complete all requested land restitution file cases. At the current slow pace, financial compensation alone would take more than 20 years to complete. The fact that Arabs had accepted compensation money, received funding but then did not leave for good but used the money to renovate their homes in Kirkuk has also been the subject of criticism. How many Arabs might have acted like this is unclear. Their claim to retain a right to vote in Kirkuk remains highly controversial too. ${ }^{63}$

Land Restitution: The "Iraq Property Claims Commission (IPCC)" is currently processing applications from expropriated farmers demanding the return of some 1,200,000 Dunam $\left(2500 \mathrm{~m}^{2}\right)$ of agricultural land. As of 2015, IPCC's Kirkuk office audited around 8800 such controversial cases (MERI 2015: 18). The number who received a positive response, or was turned down, is not available. The authorities are also accused of being dilatory and of imposing excessive conditions. As of 2015, IPCC's Kirkuk office audited around 8800 such controversial cases (MERI, 2015: 18).

Census: The Federal Constitution of Iraq of 2005 mentions the term "census" only twice: in Art. 110 in the enumeration of the "exclusive remit" of the federal government in Baghdad to conduct "general population statistics" and to hold a "census" (Art 110, 9). Article 140.2 instructs the federal government to conclude a three-stage plan (normalization, census, conclusive referendum in Kirkuk and other "disputed areas") by 31 December 2007 which has not happened (Kane, 2011: p. 13: "normalization has not been completed, the long-delayed national census has been postponed four times, and no concrete steps have been taken to organize the referendum"; MERI, 2015: 20 et seq.) A credible and widely-accepted census has not taken place in Iraq since 1957 (Kane, 2011: p. 15; Stansfield \& Anderson, 2009: p. 43 et seq.). The census of 1957 is accepted by all sections of the population of Iraq as in practice the only common statistical/democratic basis. As of 2011, "it appears that the [Kirkuk] governorate currently has a Kurdish and possibly a minor Kurdish majority" (Kane, 2011: p. 27).

Elections. Kirkuk was to a large extent politically dominated by Kurds in 1991-2017. ${ }^{64}$ After the 1991 uprising, Kirkuk was directly administered by Kurds for nine days, from 19-28 March. Then US Special Forces asked representatives of the Kurds (notably the Patriotic Union of Kurdistan PUK) to withdraw from Kirkuk. US forces sought to control Kirkuk and build up a multi-ethnic administration there. ${ }^{65}$ This scenario was repeated after 2003, when Kirkuk was captured by the "Peshmerga" and PUK police units, along with US special forces, in ${ }^{63}$ MERI 2015: 17.

${ }^{64}$ The assessment by Kane, 2011: p. 23 seems somewhat exaggerated: “Despite being a recurrent arena of conflict, with the exception of nine days, March 19 to 28, during the 1991 uprising, Kirkuk has never been Kurdish administered in modern Iraqi history. This remained nominally true after 2003, when after the fall of Kirkuk to Patriotic Union of Kurdistan (PUK) peshmerga, PUK police units, and a small number of U.S. special forces in April 2003, the U.S. military took control of the city and asked its Kurdish allies to withdraw."Cf. also Derzsi-Horváth 2017: ftn. 7:

http://www.gppi.net/publications/iraq-after-isil-kirkuk (accessed 1st September 2017).

${ }^{65}$ Verbal communication, 2003 by Jalal Talabani and "Mam" Rostam (Rostam Hamid Rahim), PUK-"Peshmerga" commander, successful most notably in fierce fighting for control of Kirkuk 2003. 
April 2003. The US military took control of the city center and once again asked the Kurdish allies to withdraw from Kirkuk (Stansfield \& Anderson, 2009: pp. 92-93). In the December 2005 elections, the Kurdistan Alliance scored 53\% of the valid votes cast and, together with smaller pro-Kurdish parties, gained a slim 55\% majority (Kane, 2011: p. 25). The national parliamentary elections of March 2010 brought a more nuanced result: the Kurdish vote was spread among the "Kurdistan Alliance" (36\%), the (then new) opposition party "Gorran" (6\%) and two other smaller Kurdish Islamic parties (6\%). Kurds remained the largest political group in the Kirkuk jurisdiction, but their overall majority fell compared to 2005 , from $55 \%$ to $48 \%$. On March 29, 2011, Kirkuk-born Kurdish physician and (PUK) politician Najmaddin Kareem was elected governor of Kirkuk. Kareem held office from 2011-2017, and in the national parliamentary elections in 2014 also secured clear voter approval, tried to maneuver for Kurdish presence in Kirkuk but failed, was then dismissed on 14 October 2017 by the parliament in Baghdad for holding a unilateral Kurdish referendum in the "disputed area" of Kirkuk. He left Kirkuk soon afterwards.

\section{Acknowledgements}

The author wishes to thank the Kurdish scholars Abdol-Hamid Hosseini and Omar Sheikhmous for their valuable research contributions to this analysis. $\mathrm{He}$ is also grateful to the Edward G. Steen and Will Young for correcting the English draft of this analysis and the Kurdish young scientist Sien Khanakah for proofreading.

\section{Conflicts of Interest}

The authors declare no conflicts of interest regarding the publication of this paper.

\section{References}

Ali, O. (1992). British Policy and the Kurdish Question in Iraq, 1918-1932. Thesis, Toronto: University of Toronto.

Amarilyo, E. (2014). The Dual Relationship between Kurdish Tribalism and Nationalism. In O. Bengio (Ed.), Kurdish Awakening: Nation Building in a Fragmented Homeland (pp. 63-82). Austin: University of Texas Press.

Anderson, J. (1972). Israelis Infiltrate Arab Regimes. The Washington Post, 17 September 1972, p. B7.

Anderson, L., \& Stansfield, G. (2004). The Future of Iraq: Dictatorship, Democracy, or Division? New York: Palgrave Macmillan.

Andrew, C., \& Mitrokhin, V. (2005). The Mitrokhin Archive II. The KGB and the World. London: Penguin.

Arfa, H. (1966). The Kurds: A Historical and Political Study. London: Oxford University Press.

Atlantic Charter. (1941). Signed by Franklin D. Roosevelt \& Winston Churchill, Yale Law School, The Avalon Project. http://avalon.law.yale.edu/wwii/atlantic.asp 
Aziz, M. A. (2011). The Kurds of Iraq: Ethnonationalism and National Identity in Iraqi Kurdistan. London/New York: Tauris.

Barzani, M. (2003). Mustafa Barzani and the Kurdish Liberation Movement (1931-1961). Edited, with a General Introduction, by Ahmed Ferhadi. New York: Palgrave Macmillan. https://doi.org/10.1007/978-1-349-63384-5

Bassireh, S. (2003). Das politische System im Irak unter der Baath-Partei. Stabilisierungsund Destabilisierungsfaktoren der Baath-Herrschaft. Phil. Diss., Wuppertal: Universität Wuppertal.

Bengio, O. (1998a). Crossing the Rubicon: Iraq and the Arab-Israeli Peace Process. Meria Journal, 2, 32-41. http://www.rubincenter.org/meria/1998/03/bengio.pdf

Bengio, O. (1998b). Saddam's Word: Political Discourse in Iraq. Oxford/New York: Oxford University Press.

Black, I., \& Morris, B. (1991). Israel's Secret Wars: A History of Israel's Intelligence Services. New York: Grove Weidenfeld.

Blake, C. (2009). The U.S.-Soviet Confrontation in Iran, 1945-1962. A Case in the Annals of the Cold War. Lanham et al.: University Press of America.

Chaliand, G. (1993). A People without a Country: The Kurds and Kurdistan. London: Zed.

Cockburn, A., \& Cockburn, L. (1991). Dangerous Liaison: The Inside Story of the U.S.-Israeli Covert Relationship. New York, NY: Harper Collins.

Coene, F. (2009). The Caucasus - An Introduction. London/New York, NY: Routledge.

Eagleton, W. Jr. (1963). The Kurdish Republic of 1946 (Middle Eastern Monographs 5). London: Oxford University Press.

Elphinston, W. G. (1946). The Kurdish Question. International Affairs, 22, 91-103. https://doi.org/10.2307/3017874

Encyclopaedia Britannica (2018). Mustafa al-Barzani. Kurdish Military Leader. https://www.britannica.com/biography/Mustafa-al-Barzani

Farrokh, K. (2011). Iran at War 1500-1988. Oxford: Osprey.

Fossum, L. O. (1918). The War-Stricken Kurds. The Kurdistan Missionary, 10, 7.

Ghareeb, E. (1981). The Kurdish Question in Iraq. New York, NY: Syracuse University Press.

Gibson, B. R. (2015). Sold Out? Us Foreign Policy, Iraq, the Kurds, and the Cold War. New York, NY: Palgrave. https://doi.org/10.1057/9781137517159

Ghassemlou, A.-R. (1988). Forty Years of Struggle for Freedom: A Short History of the Kurdistan Democratic Party of Iran (2th Ed., Vol. 1).

Ghassemlou, A.-R. (1980-81). Qiade muwakada (provisorische Führung).

Ghassemlou, A.-R. (1980). Khianatakani qiadey mowaqata: Treacherous Acts of the Provisional Leadership of the KDP-Iraq 1976-1980. KDP-Iran Publication.

Ghassemlou, A.-R., \& Hessami, K. (1971). Caravan of Martyrs of Iranian Kurdistan (pp. 56-90). Baghdad: KDP-Ir Press.

Ghazi, H. (2009). Ed. \& transl.: Ludvig Olsen Fossum (1879-1920), Memories and Reports, The Kurdistan Missionary, No. 12, Sept. 1916 \& 10: 7, 1918, 5-6, Translated into Kurdish in: Mahabad Magazine, No. 71, December 2006, pp. 5-6; No. 102, September 2009, pp. 3-5; No. 105, December 2009, p. 4.

Gunter, M. (2018). Kurdish Disunity in Historical Perspective. Seton Hall Journal of Diplomacy and International Relations, 19, 26-45. 
Gunter, M. (2011). Historical Dictionary of the Kurds. Lanham/Toronto/Oxford: Scarecrow Press.

Gunter, M. (1994). Mulla Mustafa Barzani and the Kurdish Rebellion in Iraq: The Intelligence Factor. International Journal of Intelligence and Counter Intelligence, 7, 465-474. https://doi.org/10.1080/08850609408435264

Hassanpour, A. (1994). The Nationalist Movements in Azarbaijan and Kurdistan 1941-1946. In J. Foran (Ed.), A Century of Revolution (pp. 78-105). Minneapolis: University of Minnesota Press.

Hassanpour, A. (1992). Nationalism and Language in Kurdistan, 1918-1985. San Francisco, CA: Mellen Research University Press.

Hennerbichler, F. (2013). Assassination of Abdul Rahman Ghassemlou (1930-1989). New Assessment. In F. Hennerbichler, Th. Schmdinger, M. Six-Hohenbalken, \& Chr. Osztovics (Eds.), Vienna Kurdish Studies Yearbook(Vol. 1/2013, pp. 288-321). Wiener Verlag.

Hennerbichler, F. (2004). Die Kurden. Mosonmagyaróvár: A\&H Edition fhe.

Hooglund, E. (2018). In Memoriam: Amir Hassanpour (1943-2017). Middle East Critique, 27, 95-98. https://doi.org/10.1080/19436149.2018.1426687

https://www.tandfonline.com/doi/abs/10.1080/19436149.2018.1426687?.journalCode $=\mathrm{c}$ cri20

HRW Human Rights Watch (2006). Genocide in Iraq-The Anfal Campaign against the Kurds.

https://www.hrw.org/report/2006/08/14/genocide-iraq-anfal-campaign-against-kurds/r eport-summary

HRW Human Rights Watch (1993). Genocide in Iraq. The Anfal Campaign against the Kurds.

https://www.hrw.org/report/1993/07/01/genocide-iraq/anfal-campaign-against-kurds

HRW Human Rights Watch (1991). Whatever Happened to the Iraqi Kurds? Human Rights Report. https://www.hrw.org/reports/1991/IRAQ913.htm

Iraq Constitution (2005).

https://web.archive.org/web/20161128152712/http://www.iraqinationality.gov.iq/attach /iraqi_constitution.pdf

Jawad, S. (1981). Iraq and the Kurdish Question, 1958-1970. London: Ithaca Press.

Jawaideh, W. (2006). The Kurdish National Movements. Its Origins and Development. New York, NY: Syracuse University Press.

Kane, S. (2011). Iraq's Disputed Territories. A View of the Political Horizon and Implications for U.S. Policy. United States Institute of Peace. https://www.usip.org/sites/default/files/PW69_final.pdf

Katz, S. M. (1994). Soldier Spies: Israeli Military Intelligence. Novato, CA: Presidio Press.

Katzman, K. (2018). Iran's Foreign and Defense Policies. Washington DC: Congressional Research Service. https://fas.org/sgp/crs/mideast/R44017.pdf

Kechichian, J. A. (no year). BOUNDARIES iv. with Iraq. http://www.iranicaonline.org/articles/boundaries-iv

Khandagh, N. (2013). Critical Analysis of Kurds in Kurdistan (Iran) with Special Reference to Hizbe Kamala Kurdistan 1941-1947. Elite Research Journal of Education and Review, 1, 1-5. http://www.eliteresearchjournals.org/erjer/index.htm

Knights, M., \& Ali, A. (2010). Kirkuk in Transition Confidence Building in Northern Iraq. The Washington Institute for Near East Policy.

https://www.washingtoninstitute.org/uploads/Documents/pubs/PolicyFocus102.pdf 
Knights, M., \& Wahab, B. (2018). Setting the Stage for Provincial Elections in Kirkuk. The Washington Institute.

http://www.washingtoninstitute.org/policy-analysis/view/setting-the-stage-for-provinci al-elections-in-kirkuk

Koohi-Kamali, F. (2003). The Kurds and Kurdistan; The Kurdish Republic in Mahabad. In The Political Development of the Kurds in Iran (pp. 24-43, 89-125). London/New York, NY: Palgrave Macmillan. https://doi.org/10.1057/9780230535725_5

KRG GOV. (2017). The Constitutional Case for Kurdistan's Independence \& A Record of the Violation of Iraq's Constitution by Successive Iraqi Prime Ministers and Ministers, the Council of Representatives, the Shura Council, the Judiciary and the Army (pp. $1-33)$.

http://cabinet.gov.krd/uploads/documents/2017/Constitutional_violations_Sept_24_20 17.pdf

KRG Ministry of Extra Regional Affairs (2007). Report on the Administrative Changes in Kirkuk and the Disputed Regions (pp. 1-99). http://perleman.org/files/articles/130508111135.pdf

Kuniholm, B. R. (2011). AZERBAIJAN v. History from 1941 to 1947. http://www.iranicaonline.org/articles/azerbaijan-v

Laqueur, W. Z. (1956). Communism and Nationalism in the Middle East. Aylesbury/London: Routledge \& Kegam.

Lenczowski, G. (1947). The Communist Movement in Iran. Middle East Journal, 1, 29-45.

Lortz, M. G. (2005). Willing to Face Death: A History of Kurdish Military Forces-The Peshmerga-From the Ottoman Empire to Present-Day Iraq (Paper 1038). Electronic Theses, Florida State University, Treatises and Dissertations. https://fsu.digital.flvc.org/islandora/object/fsu:175614/datastream/PDF/view

Mamedova, N. M. (2009). Russia ii. Iranian-Soviet Relations (1917-1991). http://www.iranicaonline.org/articles/russia-ii-iranian-soviet-relations-1917-1991

McDowall, D. (2007). A Modern History of the Kurds. London/New York, NY: Tauris.

McLachlan, K. (2013). BOUNDARIES $i$. with the Ottoman Empire. http://www.iranicaonline.org/articles/boundaries-i

Morris, S., Wirya, K., \& Ala'Aldeen, D. (2015). The Future of Kirkuk. A Roadmap for Resolving the Status of the Governorate. Policy Report, MERI Middle East Research Institute.

http://www.meri-k.org/wp-content/uploads/2015/09/The-Future-of-Kirkuk-A-Roadm ap-for-Resolving-the-Status-of-the-Province-English.pdf

Minasian, S. (2007). The Israeli-Kurdish Relations (pp. 15-32). http://www.noravank.am/upload/pdf/256_en.pdf

Mirsky, G. (2003). The Baghdad Puzzle. Russia in Global Affairs. http://eng.globalaffairs.ru/number/n_636

Mojab, S. (2005). Kurdish Women. In S. Joseph (Ed.), Encyclopedia of Women and Islamic Cultures: Family, Law and Politics (pp. 358-366, Vol. 2). Leiden/Boston: Brill.

Mojab, S. (2001). Women and Nationalism in the Kurdish Republic of 1946. In S. Mojab (Ed.), Women of a Non-State Nation: The Kurds. Costa Mesa, CA: Mazda Publishers. http://sites.utoronto.ca/wwdl/publications/english/mojab_03.pdf

Morris, J. (1980). Begin Airs Secret Israeli Aid to Kurds as Reminder for Iraqis (p. 11). The Christian Science Monitor, 6 October 1980.

Mustafa, M. S. (2016). Iran's Role in the Kurdistan Region. Al Jazeera Centre for Studies. http://studies.aljazeera.net/en/reports/2016/04/160420105055207.html 
Nakdimon, S. (1996). A Hope That Broke, the Israeli-Kurdish Cooperation 1963-1975. Tel Aviv: Jediot Acharonot \& Chemed. (In Hebrew)

Nerwiy, H. K. T. (2012). The Republic of Kurdistan, 1946. Doctoral Thesis, Leiden: Leiden University. https://openaccess.leidenuniv.nl/handle/1887/18583

Nikitin, B. (1941). La Perse que j’ai connue, 1909-1919, typed memoir. Paris: Bibliothèque INALCO.

O’Ballance, E. (1996). The Kurdish Struggle, 1920-94. London/New York, NY: Parlgrave Macmillan. https://doi.org/10.1057/9780230377424

Orland, N. (1997). Die Kurdenpolitik Israels/Ein umstrittenes Buch. http://www.faz.net/aktuell/feuilleton/politik/rezension-sachbuch-anlass-zu-grosser-bes orgnis-11314141.html

Pelletiere, S. C. (2016). Oil and the Kurdish Question: How Democracies Go to War in the Era of Late Capitalism. Lanham, MD: Lexincton.

Pelletiere, S. C. (1991). The Kurds and Their Agas: An Assessment of the Situation in Northern Iraq. Carlisle, PA: SSI Strategic Studies Institute, U.S. Army War College.

Ramazani, R. K. (1971). The Autonomous Republic of Azerbaijan and the Kurdish People's Republic: Their Rise and Fall. Studies on the Soviet Union, 11, 401-427.

Raviv, D., \& Melman, Y. (1990). Every Spy a Prince: The Complete History of Israel's Intelligence Community. Boston: Houghton Mifflin.

Riedel, B. (2017). Masoud Barzani and the Roots of Kurdish Distrust of the United States. https://www.brookings.edu/blog/markaz/2017/11/02/masoud-barzani-and-the-roots-of -kurdish-distrust-of-the-united-states

Roosevelt, A. Jr. (1947). The Kurdish Republic of Mahabad. Middle East Journal, 1, 247-269. https://www.jstor.org/stable/pdf/4321887.pdf

Samady, A. (2006). Ed. \& Transl.: Chalniko, J.: Report on the Murder of the Russian Consul in Mahabad, Col. Alexander Ivanovitch Iyas (1869-1914), in: Mahabad Magazine, No. 69, December 2006, and Parwizyian, M.W., Memories 1920 (Handwritten in Persian), pp. 6-11 (in Kurdish).

Sheikhmous, O. (2013). United in Disunity-The Fractious Character of Kurdish Politics in Syria. https://www.academia.edu/26256139/United_in_Disunity_1_.docx

Sheikhmous, O. (1992). The Kurdish Question in Regional Politics: Possible Peaceful Solutions. In K. Rupesinghe (Ed.), Internal Conflict and Governance (pp. 130-151). London: Macmillan.

Sluglett, P., \& Farouk-Sluglett, M. (2003). Iraq since 1958: From Revolution to Dictatorship. London/New York, NY: Tauris.

Smolansky, O. M., \& Smolansky, B. M. (1991). The USSR and Iraq: The Soviet Quest for Influence. Durham/London: Duke University Press.

Stansfield, G., \& Anderson, L. (2009). Crisis in Kirkuk. The Ethnopolitics of Conflict and Compromise. Philadelphia: University of Pennsylvania Press.

Sudoplatov, P. A., \& Sudoplatov, A. (1994-1995). Special Tasks. The Memoirs of an Unwanted Witness - A Soviet Spymaster. Boston, Toronto, London, New York, NY: Little, Brown \& Co.

Transitional Administrative Law (TAL) (2004). The Coalition Provisional Authority. Law of Administration for the State of Iraq for the Transitional Period. http://web.archive.org/web/20090423064920/http://www.cpa-iraq.org/government/TA $\underline{\text { L.html }}$

Talabany, N. (1999). Iraq's Policy of Ethnic Cleansing: Onslaught to Change Nation- 
al/Demographic Characteristics of the Kirkuk Region. https://www.kurdipedia.org/files/books/2013/87924.PDF?ver=130286343280814632

UCDP Uppsala Conflict Data Program (1975). Treaty Concerning the State Frontier and Neighbourly Relations between Iran and Iraq. http://ucdp.uu.se/downloads/fullpeace/Iran-Iraq\%2019750613a.pdf

UNAMI (2009). The UN Assistance Mission in Iraq, UN Mission Submits Reports on Disputed Internal Boundaries in Northern Iraq. http://www.un.org/apps/news/story.asp?NewsID=30553\#.WmXu5JOdVmB http://www.un.org/apps/news/srory.asp?NewslD=30553\&Cr=iraq\&Cr1

UN Digital Library (1990). Letter Dated 15 August 1990 from the Permanent Representative of Iraq to the United Nations Addressed to the Secretary-General. http://digitallibrary.un.org/record/96182/files/S_21528-EN.pdf?version\%20=1

UNTC (United Nations Treaty Collection) (1975). Agreement Concerning the Rules Governing Navigation on the Shatt Al'Arab (with Exchanges of Letters). Signed at Baghdad on 26 December 1975.

https://treaties.un.org/doc/Publication/UNTS/Volume\%201017/volume-1017-I-14905English.pdf

UNTC (United Nations Treaty Collection) (1976). Treaty Series, Treaties and International Agreements Registered or Filed and Recorded with the Secretariat of the United Nations. https://treaties.un.org/doc/Publication/UNTS/Volume\%201017/v1017.pdf

Vali, A. (2011). Kurds and the State in Iran: The Making of Kurdish Identity. London/New York, NY: Tauris.

Van Bruinessen, M. (1986). Major Kurdish Organizations in Iraq, MER. Middle East Research and Information Project 141 Hidden Wars, Vol. 16, July/August 1986. https://www.merip.org/mer/mer141/major-kurdish-organizations-iran

Ward, S. R. (2009). Immortal: A Military History of Iran and Its Armed Forces. Washington DC: Georgetown University Press.

Westermann, W. L. (1946). Kurdish Independence and Russian Expansion. Foreign Affairs, 24, 675-686. https://doi.org/10.2307/20030002

Wilber, D. N. (2014). Iran, Past and Present: From Monarchy to Islamic Republic. Princeton: University Press.

Yefremenko, D. (2017). By the Rivers of Babylon. http://eng.globalaffairs.ru/number/By-the-Rivers-of-Babylon-19037

Zhdannikov, D. (2018). The Great Russian Oil Game in Iraqi Kurdistan. https://www.reuters.com/article/us-rosneft-iraq-insight/the-great-russian-oil-game-iniraqi-kurdistan-idUSKBN1HQ1R3

Zhdannikov, D. (2017). Russia's Rosneft Clinches Gas Pipeline Deal with Iraq's Kurdis$\tan$.

https://www.reuters.com/article/kurdistan-rosneft/russias-rosneft-clinches-gas-pipelin e-deal-with-iraqs-kurdistan-idUSL5N1LY0TS 


\section{Abbreviations}

AUIS: American University of Iraq Sulaimani

DA'ESH: State Islamic of Iraq and the Levant

GCC: Gulf Cooperation Council

ICG: International Crisis Group Middle East

IDP: Internally Displaced Person

INSS: Institute for National Security Studies

IPCC: Iraq Property Claims Commission

IRGC: Islamic Revolutionary Guards Corps

IRIS: Institut de Relations Internationales et Stratégiques

IRIS: Institute of Regional and International Studies

IS: Islamic State

ISF: Iraqi Security Forces

ISIL: Islamic State of Iraq and the Levant

ISIS: Islamic State of Iraq and Syria

KDP-I: Kurdistan Democratic Party Iraq

KDP-Ir: Kurdistan Democratic Party Iran

KGB: Committee for State Security (Ex-USSR, 1954-1991)

KRG: Kurdistan Regional Government

KRI: Kurdistan Region Iraq

MERI: Middle East Research Institute

NGO: Non-Government Organization

NKVD: People's Commissariat for Internal Affairs

PKK: Kurdistan Workers' Party

PM: Prime Minister

PMF: Popular Mobilization Forces

PUK: Patriotic Union of Kurdistan

PYD: Democratic Union Party

RAND: RAND Corporation (Research and Development)

RIAC: Russian International Affairs Council

SSR: Soviet Socialist Republic

TAL: Transitional Administrative Law

UCDP: Uppsala Conflict Data Program

USSR: Union of Soviet Socialist Republics

UNDP: United Nations Development Programme

UNAMI: United Nations Assistance Mission for Iraq

UNSC: United Nations Digital Library System

UNTC: United Nations Treaty Collection

UoS: University of Sulaimani

WWI: World War One

WWII: World War Two 